\title{
Hawaiian Volcanoes
} During 1950

G E O L O G I CA L S URVEY BULLETIN 996-B

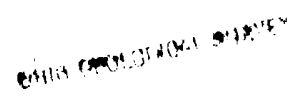

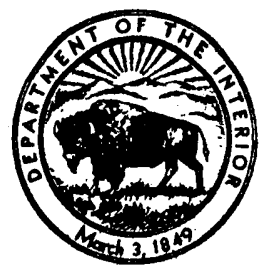





\title{
A CONTRIBUTION TO GENERAL GEOLOGY
}

\author{
HAWAIIAN VOLGANOES DURING 1950
}

\author{
By R. H. Finch and Gordon A. Macdonald
}

\begin{abstract}
ABSTRACr'
The activities of the Hawaiian Volcano Observatory during the calendar year 1950 are briefby described. Statistics on local and distant earthquakes recorded during the year, tilting of the ground surface, crack measurements, monthly rainfall statistics, and temperature measurements are presented and briefly discussed. Occurrences of warm water at several localities on the rift zones of Kilauea volcano are described. The warm water apparently results from heating of ground water by either contact with hot intrusive rock or rising hot gases.

An eruption of Mauna Loa began on the evening of June 1, and continued until June 23. Fissures opened along the southwest rift zone of Mauna Loa for a distance of more than 12 miles. At 9:04 p. m. a fissure 1.5 miles long opened between 11,000 and 12,000 feet altitude. Floods of very liquid lava poured out, and a cloud of fume rose two miles in the air, brightly illuminated by the red glare of the liquid lava beneath. This activity lasted only about four hours. At $10: 15$ p. $\mathrm{m}$. a new series of fissures started to open lower on the rift, between 8,500 and 10,500 feet altitude. Activity along the upper portion of the lower group of fissures lasted about a week, but the lower portion remained active for more than three weeks. A total of seven large lava flows poured out, both southeastward and westward. Three of the western flows entered the ocean, the first advancing down slope at an average rate of 5.8 miles an hour. The total volume of lava extruded is estimated to have been more than 600 million cubic yards. In terms of estimated volumes of lava extruded, the eruption was the largest since 1859 .
\end{abstract}

Temperatures measured ranged from $1,080^{\circ} \mathrm{C}$. at the source fountains and $1,110^{\circ}$ in the glowing throat of a spatter cone, to $840^{\circ}$ in the lava river 10 miles from the vents. Lava at $675^{\circ} \mathrm{C}$. had become immobile.

Harmonic tremor accompanying the eruption was recorded on the BoschOmori seismograph at Kilauea caldera. During the first part of the eruption the tremor was continuous, but during later stages it became intermittent, fluctations apparently correlating with variations in the amount of lava being extruded. A large number of earthquakes accompanied and directly followed the outbreak.

No surface eruptive activity occurred at Kilauea volcano during the year. Moderately strong northward tilting of the ground at the northeastern edge of Kilauea caldera preceded the Mauna Loa outbreak, and the beginning of the Mauna Loa eruption was followed by rapid southward tilting. This appears to indicate an increase of volcanic pressure under Kilauea, followed by a sudden decrease at the time of the Mauna Loa eruption.

The end of the Mauna Loa eruption was followed by a period of northward tilting at the northeastern edge of Kilauea caldera, apparently caused by re- 
sumption of pressure increase. In early December very rapid southward tilting of the ground was accompanied by more than 650 earthquakes as the entire top of Kilauea volcano subsided. The amount of 'sinking was more than one foot in the vicinity of Halemaumau. The subsidence is interpreted as resulting from decrease of volcanic pressure and withdrawal of the Kilauean magma column.

\section{INTRODUCTION}

The Geological Survey assumed responsibility for operation of the Hawaiian Volcano Observatory in December 1947. A previous report (Finch and Macdonald, 1951) briefly reviews the history of the Observatory and gives an account of its activities during 1948 and 1949. The present report continues the account of Observatory activities through the year 1950 .

\section{ACKNOWLEDGMENTS}

During the 1950 eruption of Mauna Loa, many people contributed valuable information. It is impossible to list all by name, but to all we extend our sincere thanks. Some persons should receive special mention. Colonel L. W. Bryan, then island commander of the Hawaii National Guard and island forester of the Territorial Board of Agriculture and Forestry, was exceedingly active in making observations from the air and deserves much credit for his work in keeping track of the flows and warning of danger from them during the first days of the eruption. His knowledge of the terrain was of very great aid. William Stearns and Donald Campbell of Murray Aircraft Agricultural Service contributed many excellent observations from the air. Sergeant Wilmot Vredenburg of the Hawaii Police Department passed on much information on the activity of the Kaapuna flow near the highway. Ernest Morton, manager of Kahuku Ranch, contributed information on the lava flows in the Kau District from personal observations and from those of his cowboys. Mrs. Myrtle Hansen, of Naalehu, was exceedingly helpful in relaying information from various sources in the Naalehu and Waiohinu area as well as in contributing her own observations on the lava flows and earthquakes.

Harry Blickhahn, editor of the Hilo Tribune-Herald, and Vern Hinkley, the late managing editor of the Honolulu Star-Bulletin, also were helpful in passing on information and photographs as they were received.

Pilots of Army and Navy planes made observations from the air; and several observations, as well as those made by commercial pilots, were relayed by the staff of the Civil Aeronautics Authority at Hilo.

Members of the staff of Hawaii National Park contributed many valuable observations on the flows and vent activity. F. A. Hjort, chief ranger, and V. R. Bender, ranger, made aerial observations on 
the morning of June 2 and observations on the ground at the lower line of vents on June 3 and 4. F. R. Oberhansley, superintendent, I. J. Castro, assistant superintendent, and Herbert Quick, superintendent of construction and maintenance, observed the vent activity from the air on June 3. D. H. Hubbard, naturalist, made observations from the sea and the ground at the northern side of the Honokua flow on June 2 and 3.

D. C. Cox, geologist for the Hawaiian Sugar Planters' Association, cooperated with the Volcano Observatory staff in making observations on the lava flows and the vent activity and furnished the Observatory with a complete set of his field notes.

Several members of the U. S. Geological Survey not attached to the Observatory staff also cooperated in the investigation and were of great aid in the collection of data in the field. They include C. K. Wentworth, geologist for the Honolulu Board of Water Supply and part-time geologist for the Observatory; D. A. Davis district geologist; M. H. Carson, district engineer; G. D. Robinson, assistant chief of the General Geology Branch; and Arnold Mason, geologist with the Pacific Geological Surveys Section. H. R. Joesting and J. R. Swartz of the Geophysics Branch carried on magnetometer observations during the eruption.

\section{SEISMOGRAPHS AND TILTMETERS}

An account of the seismographs and tiltmeters in operation by the Hawaiian Volcano Observatory at the close of 1949 was given in the earlier report (Finch and Macdonald, 1951). For the most part, the instrumental installations remained the same through 1950. Several minor changes are described in the following paragraphs.

Early in September a Sprengnether vertical seismograph was installed in the Uwekahuna seismograph vault. However, the instrument was operated only for brief periods on an experimental basis, because of the lack of electric power at the Uwekahuna station. During the short periods of experimental operations the recorder for the instrument was driven by storage batteries and a DC-AC inverter. It is planned at an early date to install an electric power line from the generator plant at the Observatory building to the Uwekahuna vault, after which the Sprengnether seismograph will be put into regular operation.

During early March a semiportable tiltmeter, of the sort described. in the first annual report of the Hawaiian Volcano Observatory (Finch and Macdonald, 1951, p. 108-109), was installed in the Uwekahuna vault. This instrument operated alongside the regular horizontal pendulum tiltmeter until October, when the heavy pendulums were removed for conversion to a seismograph for the Hilo 
station. For the rest of the year the semiportable tiltmeter operated alone in the Uwekahuna vault. During the time both were in operation, there was fairly good agreement in the readings of the two tiltmeters.

The new Hilo seismograph station was completed during October, and the first record was obtained from the new instrument on October 23. The first seismograph station in Hilo was established during 1921, when a seismograph constructed by Dr. Arnold Romberg in the shop of the Hawaiian Volcano Observatory was installed in the basement of one of the buildings of St. Mary's School on Waianuenue Street. The original instrument was a one-component, short-period, normal pendulum with a magnification of 25 . During 1927 an underground vault was excavated on the school ground, and in it was installed a Hawaiian-type, two-component, horizontal pendulum seismograph. The new location was satisfactory until a few years ago, when a new road, Laimana Street, was cut through only 15 feet from the vault. After that time the traffic disturbance became increasingly troublesome.

Early in 1950 a new building was constructed by the Hawaiian Volcano Research Association on the grounds of the St. Joseph's School, 80 feet northwest of Hualalai Street, between Ululani and Kapiolani Streets. The building is of frame construction, with sheet aluminum roof, set on a 10- by 12 -foot concrete slab. The seismograph piers are set into lava rock and are isolated from the floor slab by half-inch sheets of tar-impregnated, cane-fiberboard. In October 1950 the heavy pendulums, which had been operating as a tiltmeter at the Uwekahuna station, were converted into a seismograph and installed in the new Hilo station. Although the building is entirely above ground level, effects of temperature changes on the instrument have not been severe. Ground tilting is not measured at the Hilo station.

The new Hilo instrument, a modification of the Bosch-Omori type seismograph, was constructed by B. J. Loucks in the shop of the Volcano Observatory. It consists of two horizontal pendulums, suspended respectively in north-south and east-west azimuths. Each heavy mass is a cylinder 8.6 inches in diameter, weighing 250 pounds, hinged to the base of the concrete piers by Cardan hinges, and supported by piano wire suspensions. The booms are 87 centimeters long with oil damping. They are attached to magnifying levers with a ratio of $1: 25$. Operated at a period of 3 seconds, the pendulums have a static magnification of 200 . The instrument records mechanically on smoked paper on a drum which revolves at a rate of 30 millimeters a minute. The drum is driven by a Syncron alternating-current motor. Figure 1 is a view of the interior of the Hilo station. 


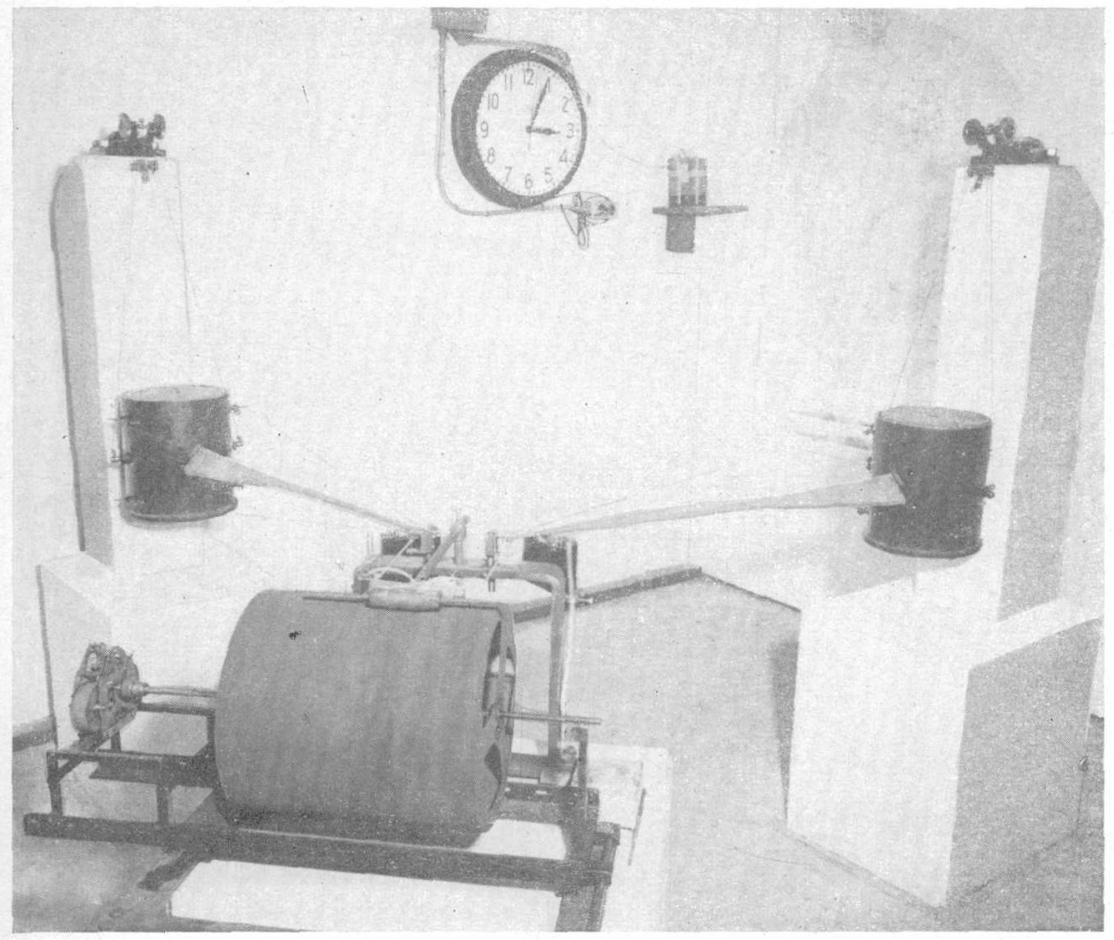

Figure 1.- Interior of the Hilo seismograph station of the Hawaiian Volcano Observatory, at St. Joseph' School. Photo by Niso Imamura, Hilo Camera Co.

During September a new Standard self-winding clock, with an invar pendulum, was installed in the Whitney vault at the northeastern edge of Kilauea caldera (fig. 2). This clock supplies time control for the Bosch-Omori seismograph and is corrected night and morning to correspond with the Bureau of Standards radio time signal. The clock error seldom exceeds 0.1 second. The Howard hand-wound, pendulum clock, which was used for many years in the Whitney vault, was moved to the Volcano Observatory building, and is now used to provide time control on the vertical seismograph in the Uwekahuna vault.

The table on page 32 lists the seismographs and tiltmeters in operation by the Hawaiian Volcano Observatory at the end of 1950, together with their principal constants, and the location of the station. The positions of the stations are shown in figure 2 on page 34 .

\section{RECORDS AND INVESTIGATIONS EARTHQUAKES}

A total of 1,702 local earthquakes was recorded on Volcano Observatory seismographs during 1950. The number of earthquakes $253280-53-2$ 
Seismographs and tiltmeters operated by the Hawaiian Volcano Observatory during 1950

\begin{tabular}{|c|c|c|c|c|c|c|}
\hline Station & $\begin{array}{l}\text { Latitude } \\
\text { (north) }\end{array}$ & $\begin{array}{l}\text { Longitude } \\
\text { (west) }\end{array}$ & Instrument & $\begin{array}{c}\text { Period } \\
\text { of pen- } \\
\text { dulum } \\
\text { (seconds) }\end{array}$ & $\begin{array}{l}\text { Magnif- } \\
\text { cation } \\
\text { (approx- } \\
\text { imate) }\end{array}$ & $\begin{array}{c}\text { Sensi- } \\
\text { tivity to } \\
\text { tilt } \\
\text { (seconds } \\
\text { of arc per } \\
\text { milli- } \\
\text { meter) }\end{array}$ \\
\hline $\begin{array}{l}\text { Whitney Laboratory of } \\
\text { Seismology (NE. rim } \\
\text { Kilauea caldera). }\end{array}$ & $19^{\circ} 25^{\prime} 53^{\prime \prime}$ & $155^{\circ} 15^{\prime} 40^{\prime \prime}$ & $\begin{array}{l}\text { Bosch-Omori seismo- } \\
\text { graph and tiltmeter. }\end{array}$ & 7.7 & 115 & 0.12 \\
\hline $\begin{array}{l}\text { Mauna Loa (6,600 feet } \\
\text { altitude on E. slope of } \\
\text { Mauna Loa). }\end{array}$ & $19^{\circ} 29^{\prime} 32^{\prime \prime}$ & $155^{\circ} 23^{\prime} 29^{\prime \prime}$ & $\begin{array}{l}\text { Hawaiian-type seismo- } \\
\text { graph. }\end{array}$ & 7.1 & 115 & .14 \\
\hline $\begin{array}{l}\text { Uwekahuna }(1,000 \text { fect } \\
\text { west of W. rim of Ki- } \\
\text { lauea crater). }\end{array}$ & $19^{\circ} 25^{\prime} 26^{\prime \prime}$ & $155^{\circ} 17^{\prime} 36^{\prime \prime}$ & Vertical seismograph_ & .4 & 250 & None \\
\hline Do & $19^{\circ} 25^{\prime} 26^{\prime \prime}$ & $155^{\circ} 17^{\prime} 36^{\prime \prime}$ & $\begin{array}{l}\text { N-S and E-W hori- } \\
\text { zontal pendulum } \\
\text { tiltmeters. }\end{array}$ & 34.0 & 7 & .13 \\
\hline Do & $19^{\circ} 25^{\prime} 26^{\prime \prime}$ & $155^{\circ} 17^{\prime} 36^{\prime \prime}$ & ....do.1.... & 20.0 & 15 & .08 \\
\hline Hilo (St.Joseph's School). & $19^{\circ} 43^{\prime} 11^{\prime \prime}$ & $155^{\circ} 05^{\prime} 20^{\prime \prime}$ & $\begin{array}{l}\text { Hawaiian-type seismo- } \\
\text { graph. }\end{array}$ & 7.3 & 115 & .13 \\
\hline $\begin{array}{l}\text { West tilt cellar (floor of } \\
\text { Kilauea caldera W. of } \\
\text { Halemaumau). }\end{array}$ & & & $\begin{array}{l}\text { Normal pendulum } \\
\text { tiltmeter. }\end{array}$ & 3 & 100 & 1.3 \\
\hline $\begin{array}{l}\text { Kona (Konawaena School, } \\
\text { Kealakekua). }\end{array}$ & $19^{\circ} 30^{\prime} 47^{\prime \prime}$ & $155^{\circ} 55^{\prime} 07^{\prime \prime}$ & $\begin{array}{l}\text { Haw:iian-type seismo- } \\
\text { graph. }\end{array}$ & 7.3 & 115 & .13 \\
\hline $\begin{array}{l}\text { Southeast tilt cellar (floor } \\
\text { of Kilauea caldera SE. } \\
\text { of Halemaumau). }\end{array}$ & & & $\begin{array}{l}\text { Normal pendulum } \\
\text { tiltmeter. }\end{array}$ & 3 & 100 & 1.3 \\
\hline
\end{tabular}

1 Semiportable.

recorded per week on the Bosch-Omori seismograph at the Whitney station, at the northeastern rim of Kilauea caldera ranged from 3 to 384. The most frequent number was 7 , followed closely by 9,4 , and 3. Thus, excluding earthquake swarms which were responsible for three brief periods of very high totals, the average for the year was approximately one earthquake a day. The number of earthquakes per week recorded at the Whitney station is shown graphically in figure 3. The table following lists the weekly totals for the Whitney and Mauna Loa stations.

Earthquake swarms occurred in the intervals from May 27 to June 14, July 30 to August 7, and December 1 to 15 . The swarm during late May and early June directly preceded and accompanied the eruption of Mauna Loa which started on June 1. The swarm early in December occurred during a subsidence of Kilauea volcano. 
Number of local earthquakes per weet recorded during 1950 at the Whitney and Mauna Loa stations of the Hawaiian Volcano Observatory

\begin{tabular}{|c|c|c|c|c|c|}
\hline Week beginning & $\begin{array}{l}\text { Whitney } \\
\text { station }\end{array}$ & $\begin{array}{l}\text { Mauna Loa } \\
\text { station }\end{array}$ & Week beginning & $\begin{array}{l}\text { Whitney } \\
\text { station }\end{array}$ & $\begin{array}{l}\text { Mauna Loa } \\
\text { station }\end{array}$ \\
\hline Jan. $1 \ldots$ & 4 & 6 & July $2 \ldots$ & 5 & \\
\hline 8 & 4 & 6 & 9 & 4 & \\
\hline $15 \ldots \ldots$ & 5 & 5 & $16 \ldots \ldots$ & 9 & \\
\hline $22 \ldots \ldots$ & 3 & 5 & $23 \ldots \ldots$ & 28 & \\
\hline 29 & 3 & 2 & $30 \ldots$ & 270 & 9 \\
\hline Feb. 5 & 4 & 4 & Aug. 6 & 29 & 15 \\
\hline $12 \ldots$ & 3 & 7 & 13 & $1 \dot{6}$ & 2 \\
\hline $19 \ldots$ & 7 & 9 & $20 \ldots \ldots$ & 3 & 5 \\
\hline 26 & 6 & 6 & $27 \ldots \ldots$ & 6 & 3 \\
\hline Mar. 5 5 & 9 & 6 & Sept. $3 \ldots \ldots$ & 7 & 7 \\
\hline 12 & 10 & 1 & 10 & 4 & 1 \\
\hline $19 \ldots$ & 9 & 3 & $17 \ldots \ldots$ & 7 & 2 \\
\hline $26 \ldots$ & 13 & 8 & $24 \ldots \ldots$ & 4 & 3 \\
\hline Apr. 2 & 11 & 7 & Oct. $1 \ldots$ & 6 & 1 \\
\hline 9 & 7 & 9 & 8 & 9 & 9 \\
\hline $16 \ldots$ & 12 & 11 & $15 \ldots \ldots$ & 5 & 5 \\
\hline $23 \ldots \ldots$ & 22 & 20 & $22 \ldots \ldots \ldots$ & 3 & 3 \\
\hline 30 & 30 & 24 & 29 & 7 & 6 \\
\hline May $7 \ldots \ldots$ & 21 & 20 & Nov. 5 & 10 & 1 \\
\hline 14 & 18 & 18 & $12 \ldots$ & 9 & 4 \\
\hline $21 \ldots \ldots$ & 9 & 10 & $19 \ldots$ & 8 & 4 \\
\hline 28 & 58 & 61 & $26 \ldots \ldots$ & 7 & 7 \\
\hline June 4 & 158 & 159 & Dec. 3 & 289 & (1) \\
\hline 11 & 60 & 60 & 10 & 384 & (1) \\
\hline $18 \ldots$ & 11 & 13 & $17 \ldots \ldots$ & 17 & 10 \\
\hline \multirow[t]{2}{*}{$25 \ldots \ldots$} & 7 & 5 & $24 \ldots \ldots$ & 9 & 5 \\
\hline & & & $31 \ldots \ldots$ & 7 & 7 \\
\hline
\end{tabular}

1 Instrument not operating.

The earthquake swarm during early August originated in Kilauea volcano. Most of the quakes originated at a shallow focus under the northern portion of Kilauea caldera. Shaking was nearly continuous on August 2, when 241 quakes were recorded at the Whitney station. Most of the quakes were small, 202 of them being classified as tremors (double amplitude of less than $1 / 2$ millimeter on Bosch-Omori seismograph). Only three of the quakes on August 2 were felt even near their epicenters. The shallow origin of the quakes is demonstrated by the fact that only 9 of the total of 270 during the week starting July 30 were recorded at the Mauna Loa station, 9.5 miles away. The earthquake swarm occurred during a period of rapid northward tilting of the ground surface at the northern edge of Kilauea caldera, which was believed to have been caused by an increase of volcanic pressure beneath the caldera. Probably the upward doming of the 


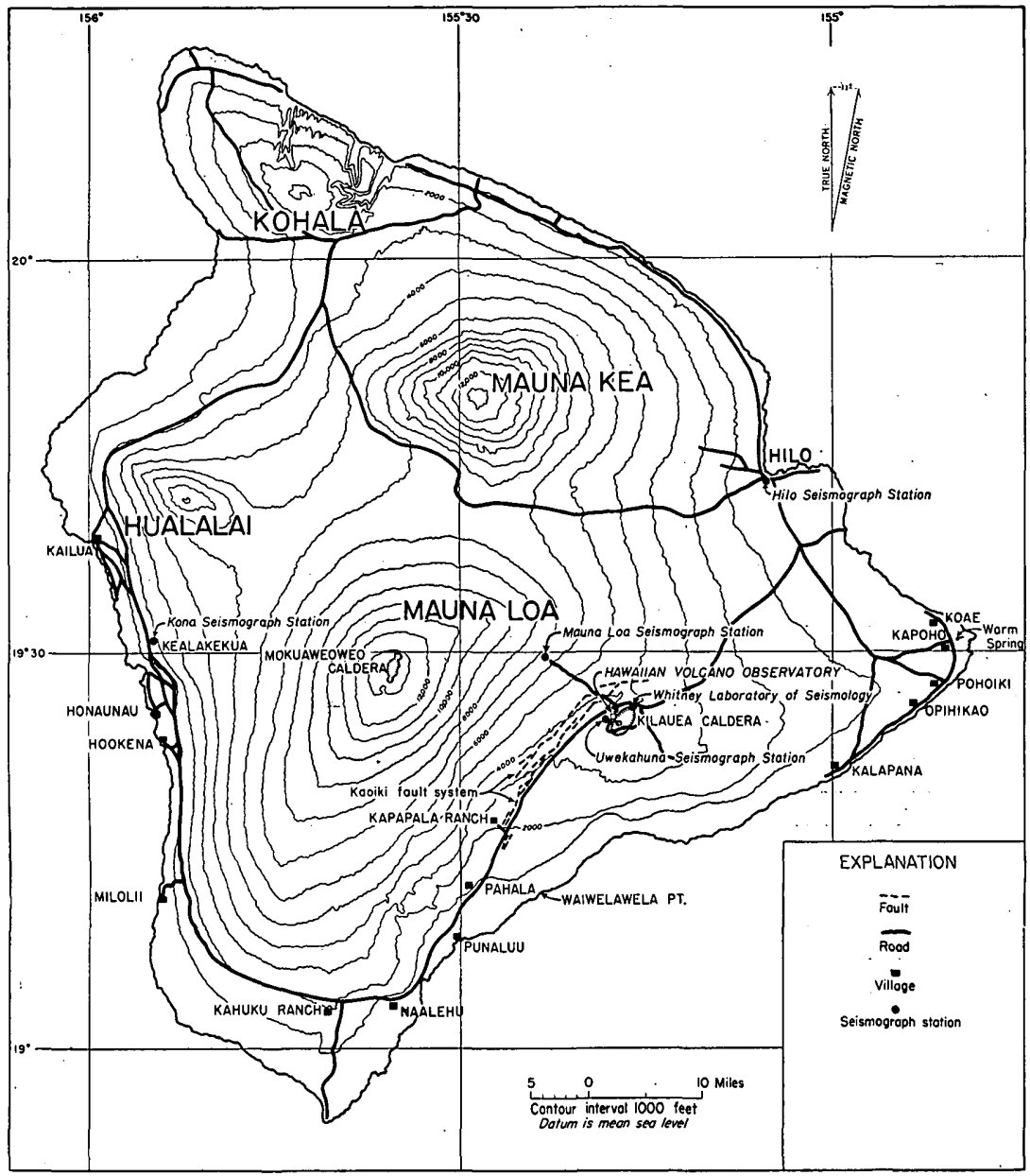

Figure 2.-Map showing location of the Hawaiian Volcano Observatory and seismograph stations.

summit area of the volcano caused a shifting of the blocks composing that portion of the mountain, and the earthquakes resulted from fault movement between adjacent blocks.

Each earthquake during the year is classified according to an arbitrary intensity scale based on the maximum displacement it produced on the Bosch-Omori seismograph. The scale is as follows:

$$
\begin{array}{cc}
\text { Intensity of earthquake } & \begin{array}{c}
\text { Double amplitude of motion } \\
\text { on Bosch-Omori seismograph } \\
\text { (millimeters) }
\end{array}
\end{array}
$$

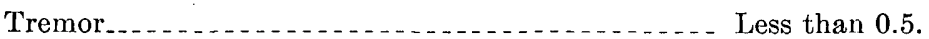

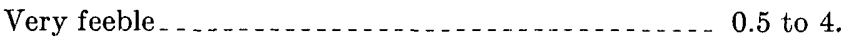

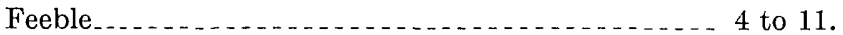

Slight__._.

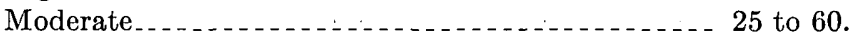

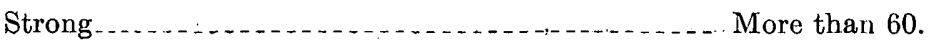




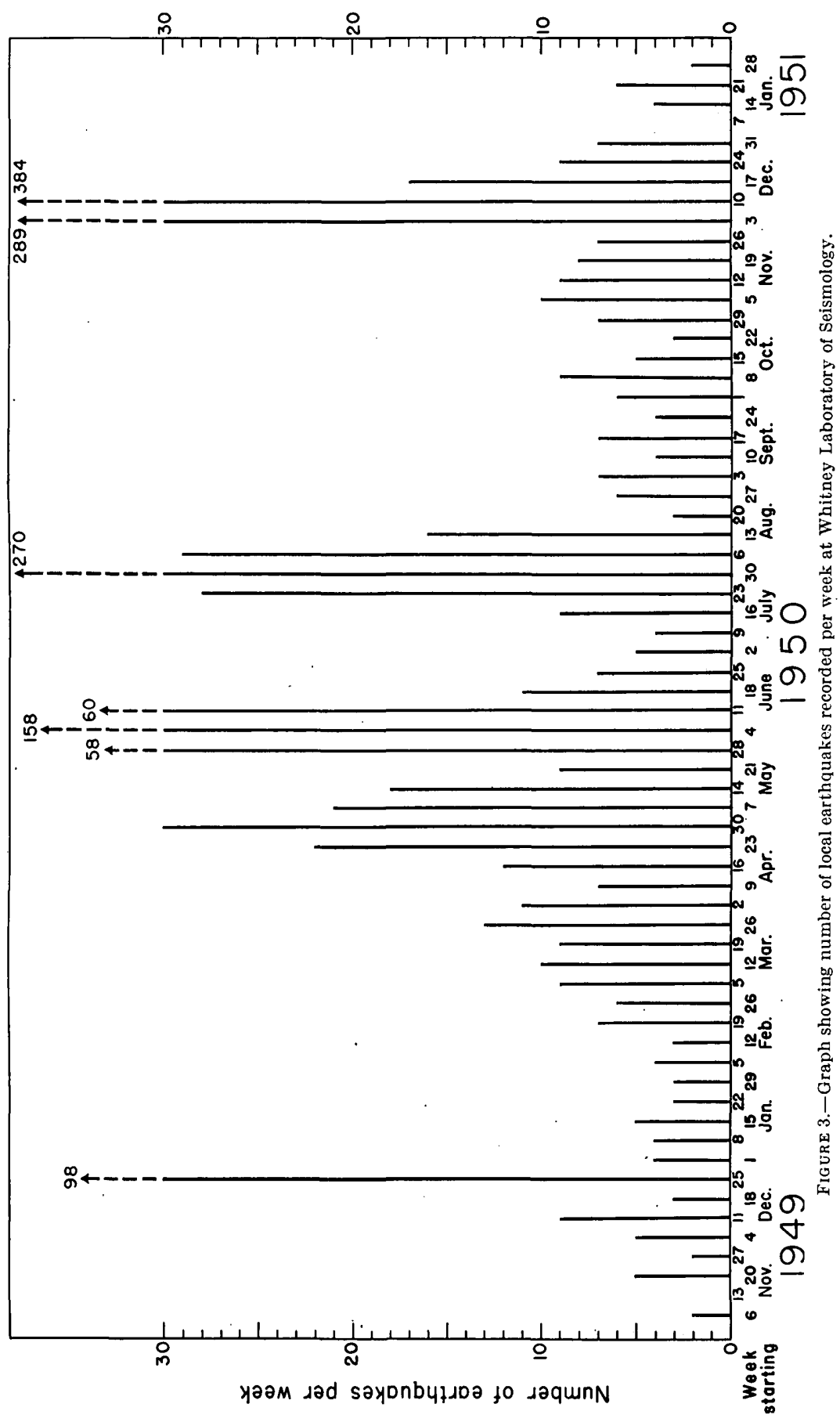


The following table is a list of local earthquakes larger than tremors recorded at the Whitney station during the year. Data for quakes were determined from records obtained at the five seismograph stations operated by the Hawaiian Volcano Observatory on the island of Hawaii (fig. 2). The arrival times are given to the closest minute in Hawaiian standard time, 10 hours slower than Greenwich civil time. The number preceding each earthquake is the serial number for the year. Locations given are epicenters. The intensity rating is that for the Whitney station. A list of distant earthquakes also follows:

Local earthquakes larger than tremors recorded at Hawaiian Volcano Observatory during 1950

\begin{tabular}{|c|c|c|c|}
\hline Serial no. & Date & $\begin{array}{l}\text { Time } \\
\text { (Hawaiian } \\
\text { Standard) }\end{array}$ & $\begin{array}{l}\text { Intensity at Whitney station and location of epicenter when } \\
\text { determinable }\end{array}$ \\
\hline 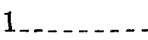 & Jan. 13 & 1154 & Very feeble. Inland from Kealakekua Bay. \\
\hline $2 \ldots \ldots \ldots$ & Jan. 20 & 1931 & Very feeble. Mauna Loa. \\
\hline $3 \ldots$ & Jan. 21 & 0440 & Very feeble. Near summit of Mauna Loa. \\
\hline 4...- & Jan. 25 & 1626 & Feeble. Felt at 29 Miles and Hilo. \\
\hline $5 \ldots \ldots \ldots$ & Feb. 12 & 0609 & $\begin{array}{l}\text { Slight. Felt locally and at Naalehu. Near } \\
\text { Makaopuhi. }\end{array}$ \\
\hline $6 \ldots \ldots$ & Feb. 13 & 1159 & $\begin{array}{l}\text { Slight. Felt locally and at Hilo. Eight miles } \\
\text { under E. slope of Mauna Loa. }\end{array}$ \\
\hline 7... & Feb. 15 & 1652 & Very feeble. Mauna L̇oa. \\
\hline $8 \ldots$ & Feb. 19 & 0800 & Very feeble. \\
\hline $9 \ldots \ldots$ & Feb. 26 & 1401 & Very feeble. Kilauea. \\
\hline $10 \ldots \ldots$ & Feb. 28 & 0426 & Very feeble. Mauna Loa. \\
\hline $11 \ldots$ & Mar. 1 & 0800 & Feeble. SW. of Hilo. \\
\hline $12 \ldots \ldots . . .$. & Mar. 7 & 2147 & Very feeble. Mauna Loa. \\
\hline $13 \ldots \ldots$ & Mar. 11 & 1959 & Very feeble. Kilauea. \\
\hline $14 \ldots$ & Mar. 17 & 0235 . & Slight. Shallow, under Kilauea. \\
\hline $15 \ldots \ldots$ & Mar. 17 & 0405 & Very feeble. \\
\hline $16 \ldots \ldots \ldots$ & Mar. 24 & 1414 & Slight. Shallow, under Kilauea. \\
\hline $17 \ldots$ & Mar. 25 & 0543 & $\begin{array}{l}\text { Strong. Widely felt on Hawaii. Seismo- } \\
\text { graphs dismantled. 15-20 miles deep under } \\
5,000 \text {-foot contour on east slope of Mauna } \\
\text { Loa. }\end{array}$ \\
\hline $18 \ldots$ & Mar. 28 & 1057 & Very feeble. Mauna Loa. \\
\hline $19 \ldots$ & Mar. 31 & 0343 & Very feeble. Kilauea. \\
\hline $20 \ldots \ldots$ & Apr. 5 & 0450 & Feeble. Felt locally. Kilauea. \\
\hline $21 \ldots \ldots$ & Apr. 8 & 0035 & Feeble. Mauna Loa. \\
\hline $22 \ldots \ldots$ & Apr. 23 & 0115 & Very feeble. Kilauea. \\
\hline $23 \ldots \ldots$ & Apr. 25 & 1009 & Very feeble. Mauna Loa. \\
\hline $24 \ldots \ldots$ & Apr. 27 & 2353 & Very feeble. Kilauea. \\
\hline $25 \ldots \ldots$ & Apr. 28 & 0226 & Feeble. Kilauea. \\
\hline $26 \ldots \ldots$ & Apr. 29 & 2111 & Very feeble. Mauna Loa. \\
\hline $27 \ldots \ldots$ & May 3 & 0348 & Very feeble. \\
\hline $28 \ldots \ldots \ldots$ & May & 1208 & Mauna Loa. \\
\hline $29 \ldots \ldots$ & May & 2219 & Very feeble. \\
\hline $30 \ldots \ldots . .$. & May 4 & 0101 & Very feeble. \\
\hline
\end{tabular}


Local earthquakes larger than tremors recorded at Hawaiian Volcano Observatory during 1950-Continued

\begin{tabular}{|c|c|c|c|}
\hline Serial no. & Date & $\begin{array}{l}\text { Time } \\
\text { (Hawaiian } \\
\text { Standard) }\end{array}$ & $\begin{array}{l}\text { Intensity at Whitney station and location of epicenter when } \\
\text { determinable }\end{array}$ \\
\hline $31 \ldots \ldots$ & May 4 & 0435 & Feeble. \\
\hline $32 \ldots \ldots$ & May & 0551 & Slight. Felt Kapapala. \\
\hline $33 \ldots$ & May & 0554 & Very feeble. Felt Kapapala. \\
\hline $34 \ldots \ldots$ & May & 0602 & Do. \\
\hline $35 \ldots \ldots$ & May & 0731 & Very feeble. \\
\hline $36 \ldots \ldots$ & May & 0347 & Do. \\
\hline $37 \ldots \ldots$ & May & 0310 & Very feeble. Mauna Loa. \\
\hline $38 \ldots \ldots$ & May & 1201 & Very feeble. \\
\hline $39 \ldots \ldots$ & May 9 & 1241 & Very feeble. Mauna Loa. \\
\hline $40 \ldots \ldots$ & May 11 & 1306 & Very feeble. \\
\hline $41 \ldots \ldots$ & May 11 & 1938 & Feeble. Mauna Loa. \\
\hline $42 \ldots \ldots$ & May 13 & 0927 & Very feeble. Mauna Loa. \\
\hline $43 \ldots$ & May 14 & 1839 & Feeble. Mauna Loa. \\
\hline $44 \ldots \ldots$ & May 18 & 1047 & Very feeble. Mauna Loa. \\
\hline $45 \ldots \ldots$ & May 18 & 1444 & Do. \\
\hline $46 \ldots$ & May 19 & 0002 & Do. \\
\hline $47 \ldots$ & May 20 & 0157 & Do. \\
\hline $48 \ldots$ & May 26 & 0145 & Do. \\
\hline $49 \ldots \ldots$ & May 27 & 1133 & Very feeble. Kilauea. \\
\hline $50 \ldots \ldots$ & May 28 & 0827 & Very feeble. Mauna Loa. \\
\hline $51 \ldots \ldots$ & May 29 & 1517 & $\begin{array}{l}\text { Strong. Upper southwest rift of Mauna Loa. } \\
\text { Widely felt. All instruments dismantled. } \\
\text { Damage to water tanks, stone walls, etc., in } \\
\text { Kona. }\end{array}$ \\
\hline $52 \ldots$ & May 30 & 1437 & Very feeble. Mauna Loa. \\
\hline $53 \ldots \ldots$. & May 30 & 1728 & Slight. Mauna Loa. \\
\hline $54 \ldots \ldots$ & June 1 & 1359 & Very feeble. Mauna Loa. \\
\hline $55-58 \ldots$ & June & 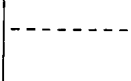 & $\begin{array}{l}\text { Mostly originating on the southwest rift of } \\
\text { Mauna Loa. }\end{array}$ \\
\hline $59-73 \ldots$ & June & $\ldots$ & Do. \\
\hline $74-91 \ldots$ & June & $-\therefore-$ & Do. \\
\hline $92-107 \ldots$ & June & 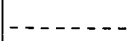 & Do. \\
\hline $108-115 \ldots$ & June & 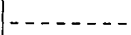 & Do. \\
\hline $116-126 \ldots$ & June & $-\ldots-n-1$ & Do. \\
\hline $127-133 \ldots$ & June & 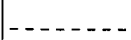 & Do. \\
\hline $134-143 \ldots$ & June 9 & $-\ldots-\ldots$ & Do. \\
\hline $144-146 \ldots$ & June 10 & $--\ldots \ldots$ & Do. \\
\hline $147-158 \ldots$ & June 11 & $\ldots \ldots$ & Do. \\
\hline $159 \ldots \ldots$ & June 12 & $\ldots-\ldots$ & Do. \\
\hline $160-164 \ldots$ & June 13 & $\ldots$ & Do. \\
\hline $165-168 \ldots$ & June 14 & $---\ldots$ & Do. \\
\hline $169 \ldots \ldots$ & June 15 & 1014 & Slight. \\
\hline $170_{\ldots} \ldots$ & June 16 & 1603 & Very feeble. \\
\hline $171 \ldots$ & June 16 & 2313 & Do. \\
\hline $172 \ldots \ldots$ & June 17 & 0631 & Do. \\
\hline $173 \ldots \ldots$ & June 19 & 0922 & $\begin{array}{l}\text { Very feeble. Felt locally. } 7 \text { miles deep, east } \\
\text { slope of Mauna Loa near Ohaikea. }\end{array}$ \\
\hline
\end{tabular}


Local earthquakes larger than tremors recorded at Hawaiian Volcano Observatory during 1950-Continued

\begin{tabular}{|c|c|c|c|}
\hline Serial no. & Date & $\begin{array}{c}\text { Time } \\
\text { (Hawaiian } \\
\text { Standard) }\end{array}$ & $\begin{array}{l}\text { Intensity at Whitney station and location of epicenter when } \\
\text { determinable }\end{array}$ \\
\hline $174 \ldots \ldots$ & June 21 & 0706 & Moderate. Felt locally. Kilauea. \\
\hline $175 \ldots \ldots$ & June 21 & 0803 & Very feeble. \\
\hline $176 \ldots \ldots$ & June 21 & 0829 & Do. \\
\hline $177 \ldots \ldots$ & June 26 & 1956 & Feeble. Felt at Naalehu. \\
\hline $178 \ldots \ldots$ & July 1 & 1255 & Very feeble. Mauna Loa. \\
\hline $179 \ldots \ldots$ & July 12 & 0312 & Very feeble. Kilauea. \\
\hline $180 \ldots \ldots$ & July 12 & 2046 . & Very feeble. East slope Mauna Loa. \\
\hline $181 \ldots$ & July 19 & 2048 & Very feeble. Southwest slope Mauna Loa. \\
\hline $182 \ldots \ldots$ & July 20 & 0345 & Very feeble. West slope Mauna Loa. \\
\hline $183 \ldots \ldots$ & July 21 & 1.529 & Very feeble. Kilauea. \\
\hline $184 \ldots$ & July 23 & 1311 & Do. \\
\hline $185 \ldots$ & July 24 & 1542 & $\begin{array}{l}\text { Feeble. Felt locally. North end Kilauea } \\
\text { caldera. }\end{array}$ \\
\hline $186 \ldots \ldots$ & July 25 & 1930 & Very feeble. Kilauea. \\
\hline $187 \ldots \ldots$ & July 26 & 1214 & Feeble. Mauna Loa. \\
\hline $188 \ldots$ & July 29 & 1856 . & Very feeble. Kilauea. \\
\hline 189 & July 31 & 0429 & $\begin{array}{l}\text { Slight. Felt locally. North end. Kilauea } \\
\text { caldera. }\end{array}$ \\
\hline $190_{--1 \ldots}$ & July 31 & 1518 & Very feeble. Kilauea. \\
\hline $191 \ldots$ & Aug. 1 & 0257 & Do. \\
\hline $192 \ldots \ldots$ & Aug. 1 & 2043 & Do. \\
\hline $193-231 \ldots$ & Aug. 2 & $-\ldots$ & $\begin{array}{l}\text { Quakes originating under north end of Kilauea } \\
\text { caldera. }\end{array}$ \\
\hline $232 \ldots$ & Aug. 3 & 02.15 & Very feeble. \\
\hline $233 \ldots$ & Aug. 3 & 0443 & Do. \\
\hline $234 \ldots \ldots$ & Aug. 8 & 0604 & Very feeble. Kilauea. \\
\hline $235 \ldots$ & Aug. 8 & 1021 & Do. \\
\hline $236 \ldots \ldots$ & Aug. 9 & 1427 & Do. \\
\hline $237 \ldots \ldots$ & Aug. 10 & 0735 & Very feeble. \\
\hline $238 \ldots \ldots$ & Aug. 11 & 1058 & Feeble. Felt at Naalehu. \\
\hline $239 \ldots \ldots$ & Aug. 13 & 05.15 & Very feeble. Kilauea. \\
\hline $240_{-\ldots} \ldots$ & Aug. 19) & 0512 & Very feeble. Felt locally. Kilauea. \\
\hline $241 \ldots$ & Aug. 27 & 1218 & $\begin{array}{l}\text { Feeble. Felt locally and at Hilo. North slope } \\
\text { Mauna Loa. }\end{array}$ \\
\hline $242 \ldots$ & Aug. 28 & 1025 & $\begin{array}{l}\text { Very feeble. Upper northeast rift of Mauna } \\
\text { Loa. }\end{array}$ \\
\hline $243 \ldots \ldots$ & Sept. 15 & 0742 & Very feeble. Kilauea. \\
\hline $244 \ldots \ldots$ & Sept. 16 & 2151 & $\begin{array}{l}\text { Feeble. Felt locally and at Hilo. Northeast } \\
\text { rift Mauna Loa. }\end{array}$ \\
\hline $245 \ldots \ldots$ & Sept. 30 & 1706 & Very feeble. Mauna Loa. \\
\hline $246 \ldots \ldots$. & Oct. 8 & 0549 & Very feeble. \\
\hline 247 & Oct. 11 & 2006 & $\begin{array}{l}\text { Slight. Felt over most of Hawaii. 20-25 } \\
\text { miles deep under east slope of Mauna Loa. }\end{array}$ \\
\hline $248 \ldots \ldots$ & Oct. 12 & 0733 & Very feeble. \\
\hline $249 \ldots$ & Oct. 31 & 0253 & Do. \\
\hline $250 \ldots \ldots$ & Nov. 1 & 1528 & Very feeble. \\
\hline $251 \ldots \ldots$ & Nov. 4 & 0302 & Do \\
\hline
\end{tabular}


Local earthquakes larger than tremors recorded at Hawaiian Volcano Observatory during 1950-Continued

\begin{tabular}{|c|c|c|c|}
\hline Serial no. & Date & $\begin{array}{l}\text { Time } \\
\text { (Hawaiian } \\
\text { Standard) }\end{array}$ & $\begin{array}{l}\text { Intensity at Whitney station and location of epicenter when } \\
\text { determinable }\end{array}$ \\
\hline 2 & Nov. 11 & 2334 & Very feeble. Kilauea. \\
\hline 3.- & Nov. 13 & & Do. \\
\hline 4. & ov. 19 & & Do. \\
\hline 5. & Nov. 26 & & W. slope Mauna Loa. \\
\hline 6 & Nov. 30 & 1418 & Very feeble. \\
\hline 37 & Dec. 1 & 0137 & Very feeble. Kilauea. \\
\hline 258 & Dec. & 2054 & Very feeble. SW. slope Mauna Loa. \\
\hline 259 & Dec. & 0027 & Very feeble. \\
\hline 260. & Dec. 7 & 0540 & Very feeble. SW. slope Mauna Loa. \\
\hline $261-278$ & Dec. 8 & & $\begin{array}{l}\text { Earthquakes accompanying subsidence at } \\
\text { Kilauea. }\end{array}$ \\
\hline $279-2$ & Dec. .9 & & - Do. \\
\hline $290 \ldots$ & Dec. 9 & 0543 & $\begin{array}{l}\text { Moderate. Widely felt. East of Mauna Iki, } \\
4 \text { to } 5 \text { miles deep. }\end{array}$ \\
\hline 29$) 1-321 \ldots$ & Dec. 9 & & $\begin{array}{l}\text { Earthquakes accompanying Kilauea subsid- } \\
\text { ence. }\end{array}$ \\
\hline 322 & Dec. 9 & 2045 & $\begin{array}{l}\text { Strong. Widely felt, instruments dismantled. } \\
\text { Near Kamakaia Hills. }\end{array}$ \\
\hline $323-326$ & Dec. 9 & & $\begin{array}{l}\text { Earthquakes accompanying Kilauea subsid- } \\
\text { ence. }\end{array}$ \\
\hline $7-3$ & Dec. 10 & & Do. \\
\hline $35_{-}$ & Dec. 10 & 0557 & $\begin{array}{l}\text { Moderate. Near Kamakaia Hills, } 4 \text { to } 5 \text { miles } \\
\text { deep. }\end{array}$ \\
\hline & Dec. 10 & 0823 & Moderate. Beneath Kamakaia Hills. \\
\hline $337-368$ & Dec. 10 & ... & $\begin{array}{l}\text { Earthquakes accompanying subsidence of } \\
\text { Kilauea. }\end{array}$ \\
\hline & Dec. 10 & 1729 & Moderate. Kamakaia Hills. \\
\hline & Dec. 10 & 1757 & Moderate. Near Puu Ohale. \\
\hline & Dec. 10 & & $\begin{array}{l}\text { Earthquakes accompanying Kilauea subsi- } \\
\text { dence. }\end{array}$ \\
\hline $379_{-}$ & Dec. 10 & 2125 & $\begin{array}{l}\text { Strong. Widely felt, instrùments dismantled. } \\
\text { Origin near Kamakaia Hills. }\end{array}$ \\
\hline $380-398 \ldots$ & Dec. 10 & & $\begin{array}{l}\text { Earthquakes accompanying Kilauea subsi- } \\
\text { dence. }\end{array}$ \\
\hline & Dec. 11 & & Do. \\
\hline $421 \ldots$ & Dec. 11 & 1253 & $\begin{array}{l}\text { Moderate. Below upper end of } 1823 \text { lava } \\
\text { flow, } 4 \text { to } 5 \text { miles deep. }\end{array}$ \\
\hline $422-430 \ldots$ & Dec. 11 & & $\begin{array}{l}\text { Warthquakes accompanying Kilauea subsi- } \\
\text { dence. }\end{array}$ \\
\hline 431 & Dec. 12 & 0628 & $\begin{array}{l}\text { Moderate. Depth shallower than preceding } \\
\text { quakes. }\end{array}$ \\
\hline $432-437_{-}$ & Dec. 12 & & $\begin{array}{l}\text { Earthquakes accompanying Kilauea subsi- } \\
\text { dence. }\end{array}$ \\
\hline & & 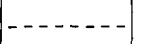 & Do. \\
\hline & Dec. 14 & 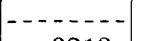 & Do. \\
\hline $448 \ldots$ & Dec. 15 & 021.3 & Very feeble. \\
\hline
\end{tabular}


Local earthquakes larger than tremors recorded at Hawaiian Volcano Observatory during 1950-Continued

\begin{tabular}{c|r|r|l}
\hline Serial no. & Date & $\begin{array}{c}\text { Time } \\
\text { (Hawaian } \\
\text { Standard })\end{array}$ & Intonsity at Whitney station and location of epicenter when \\
determinable
\end{tabular}

Distant earthquakes recorded at Hawaiian Volcano Observatory during 1950

\begin{tabular}{|c|c|c|}
\hline Date & $\begin{array}{c}\text { Time } \\
\text { (Hawaian } \\
\text { standard) }\end{array}$ & $\begin{array}{l}\text { Intensity at Whitney station and location of epicenter (from preliminary } \\
\text { determinations of epicenters by U. S. Coast and Geodetic Survey) }\end{array}$ \\
\hline Jan. 9 & 1730 & Slight. Off south coast of Mexico. \\
\hline Feb. 28 & 0030 & Slight. North coast of Hokkaido. \\
\hline Apr. 18 & 0500 & Slight. Southwest of Galapagos. \\
\hline Apr. 30 & 0100 & Slight. North of Easter Island. \\
\hline May 25 & 1527 & Slight. New Hebrides. \\
\hline June 24 & 1234 & Do. \\
\hline July 8 & 1609 & Slight. Near Easter Island. \\
\hline July 12 & 0127 & Slight. Aleutian Islands. \\
\hline July 29 & 0658 & Slight. Molucca Passage. \\
\hline July 29 & 1358 & Slight. Solomon Islands. \\
\hline Aug. 6 & 1657 & Slight. Mindanao, P. I. \\
\hline Aug. 15 & 0424 & Strong. Burma. \\
\hline Sept. 10 & 0525 & Slight. New Hebrides. \\
\hline Sept. 28 & 2036 & Moderate. Off coast of Mexico, near Colima. \\
\hline Oct. 5 & 0621 & Moderate. Costa Rica. \\
\hline Oct. 7 & 1734 & Slight. Moluccas. \\
\hline Oct. 21 & 0004 & Slight. West coast of Mexico. \\
\hline Oct. 23 & 0624 & Slight. Guatemala. \\
\hline Nov. 2 & 0540 & Moderate. Felt at Darwin, Australia. \\
\hline Nov. 7 & 1628 & Moderate. Solomon Islands. \\
\hline Nov. 9 & 1636 & Very slight. Off west coast of Mexico. \\
\hline Nov. 11 & 0004 & Do. \\
\hline Dec. 2 & 1001 & Moderate. New Hebrides. \\
\hline Dec. 4 & 0638 & Slight. New Britain. \\
\hline Dec. 9 & 1226 & Slight. Near northern border between Argentina and Chile. \\
\hline Dec. 13 & 1600 & Slight. Tonga Islands region. \\
\hline Dec. 14 & 0440 & Very slight. Northern California. \\
\hline
\end{tabular}




\section{TILTING OF THE GROUND}

Tilting of the ground surface at the Whitney station is measured by means of the Bosch-Omori seismograph. Horizontal pendulums are very sensitive to temperature changes and cannot be satisfactorily used for tilt measurement if the instrument is subjected to even moderate variation of temperature. However, at the Whitney station good insulation, a plentiful and constant supply of natural steam beneath the concrete floor, and the large heat capacity of the massive concrete piers combine to keep the vault at a nearly uniform temperature throughout the year. Under this condition the use of the BoschOmori seismograph as a tiltmeter has been found to be highly satisfactory.

Records for nearly 40 years indicate both an annual pattern of tilt, which is fairly regular from year to year, and an irregular tilting, which at least in part can be correlated with volcanic activity (Jaggar and Finch, 1929). The annual variation is believed to result partly from heating and cooling of the surrounding terrane in response to changes in average air temperature and partly from the changing direction of the gravitational pull of the sun during the shift from summer to winter (Powers, 1947). Some rapid changes over a period of a few days also can be related to temperature changes, resulting from increase or decrease of solar heating of the local terrane and cooling by large amounts of rain water percolating downward into cracks in the rocks during storms.

The average annual tilting in the north-south direction is approximately 10 seconds of arc, and that in the east-west direction is approximately 6.6 seconds of arc. On the average, from late December until mid-July, the seasonal tilting is westward; and from mid-July until December, it is eastward. Thus, eastward tilting during the fall tends to be a little more rapid than westward tilting during the spring. The asymmetry of the north-south tilt curve is even more pronounced, southward tilting continuing on the average from late December to mid-May and slower northward tilting from mid-May to December.

Part of the remaining tilt is related to volcanic activity. Thus, strong tilting in an azimuth of approximately N. $20^{\circ}$ E., the bearing of the line connecting Halemaumau, the principal center of Kilauean. activity, with the Whitney station, is directly associated with volcanic conditions at Kilauea. Prior to 1924 the behavior of the top of the Kilauea magma column was observed in the Halemaumau lava lake. Rises of lava level there, and by implication increases in volcanic pressure, were accompanied by northeastward tilting of the ground at the Whitney station. Conversely, falls of lava level were accompanied by southwestward tilting. 
The Whitney station lies almost due east of the summit of Mauna Loa; and, by analogy with the Kilauean situation, increase of volcanic pressure beneath Mauna Loa should be accompanied by an eastward tilting of the ground surface at the Whitney station. The distance of 22 miles between the station and the summit of Mauna Loa is so great that the amount of tilting expectable at the station is not large. Nevertheless, there does appear to be some correlation between east-west tilting at the Whitney station and volcanic conditions at Mauna Loa, although the correlation is less definite than that between northeast-southwest tilting and Kilauean activity.

Further statistical studies of ground tilt at the Whitney station are much needed, and are now in progress.

Figure 4 shows the tilt curves for the Whitney station for the year 1950. The curves for December 1949 and January 1951 also are shown to facilitate comparison with those in the preceding and following reports.

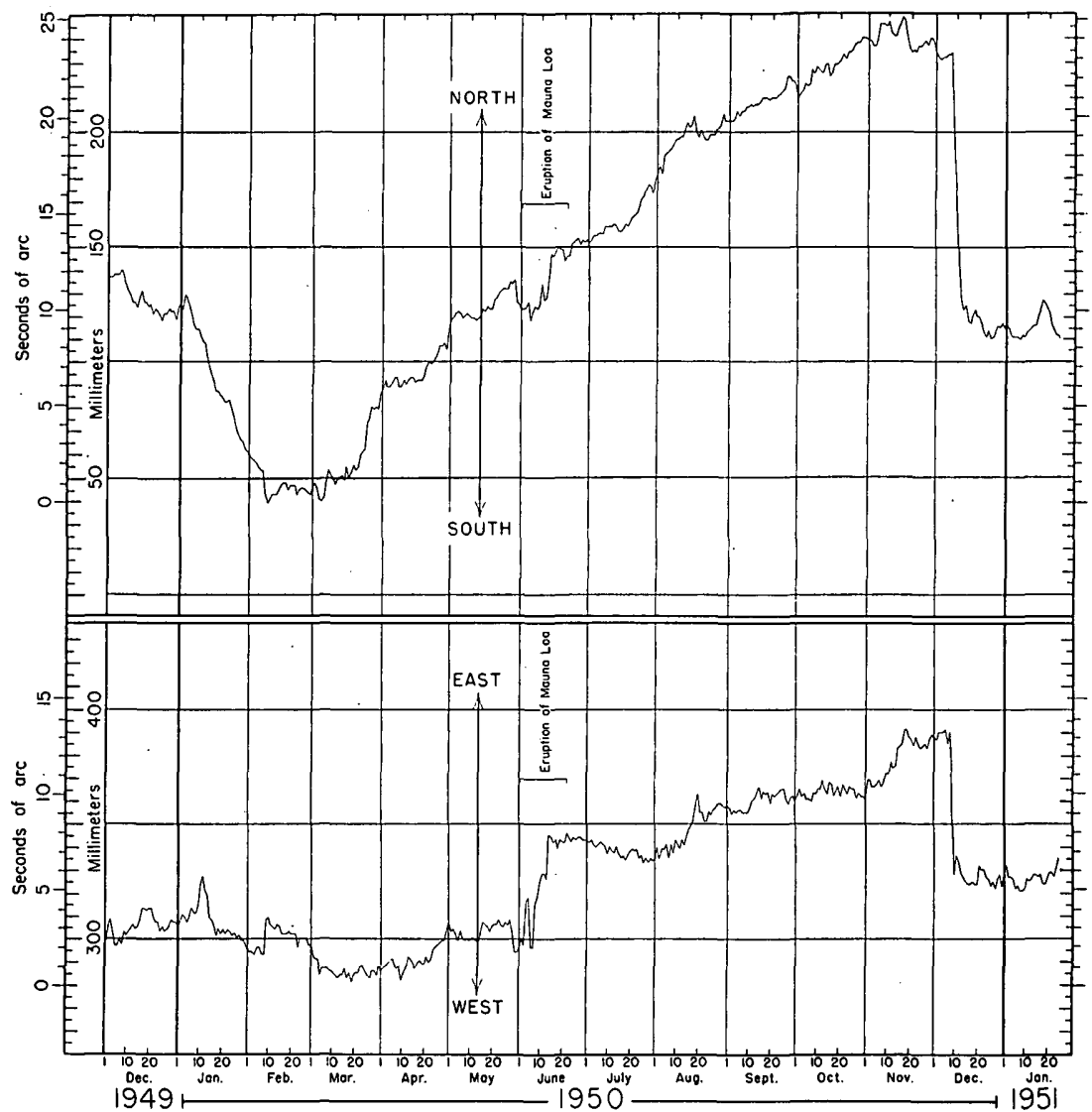

Figure 4.-Graph showing ground tilting at the Whitney Laboratory of Seismology during 1950. 
Noteworthy features of the curves are the strong oscillation of east-west tilt and rapid accumulation of eastward tilting between May 29 and June 14, just preceding and during the first half of the Mauna Loa eruption. Since mid-March there had been an eastward tilting of the ground, small and variable in rate, but distinct. This was especially striking because the normal direction of ground tilting at that season is westward. Starting early in March, there was also a rapid northward tilting of the ground, at a season when tilting normally is southward. This almost certainly reflected an accumulation of pressure beneath Kilauea and resulting tumescence of the volcano. The eastward tilting probably was partly the result of tumescence of Mauna Loa, but undoubtedly it was also in part an easterly component of the tilt caused by Kilauea. One of the major problems of the. Volcano Observatory is to determine what proportion of such eastward tilting is caused by Mauna Loa.

Just preceding and during the early part of the Mauna Loa eruption, the ground at the Whitney station tilted sharply southward, indicating a decrease of pressure beneath Kilauea apparently in sympathy with the Mauna Loa outbreak. This was followed by a rapid recovery of northward tilt during the latter part of the eruption.

Directly following the Mauna Loa eruption, eastward tilting was replaced by westward tilting, suggesting a decrease of pressure beneath Mauna Loa. During this period northward tilting continued, though at a somewhat reduced rate. From mid-July to early August northward tilting was appreciably more rapid than normal.

From early August to mid-November, northward and eastward tilting were at a rate approximately normal for that season of the year. However on November 17, marked southward tilting commenced, culminating in the big subsidence of Kilauea between December: 8 and 13. (See p. 82.) The rapid southward tilting from December 8 to 13 was accompanied by a smaller amount of westward tilting, some. of which undoubtedly was a westerly component of the tilt caused by Kilauea subsidence, but some of which may have been caused by a simultaneous decrease of pressure beneath Mauna Loa.

\section{CRACK MEASUREMENTS}

Monthly measurements of crack widths at 13 stations are shown in the following table. Crack measuring stations 5 to 9 lie along the rim crack which crosses the observation area provided for tourists at the southeastern edge of Halemaumau. Station 5, near the northern end of the crack, and station 6 , at the wall bounding the northern edge of the tourist area, showed consistent widening throughout the year. The aggregate widening at station 5 from December 30,1949 , to December 31,1950 , was 28 millimeters. That at station 6 was 


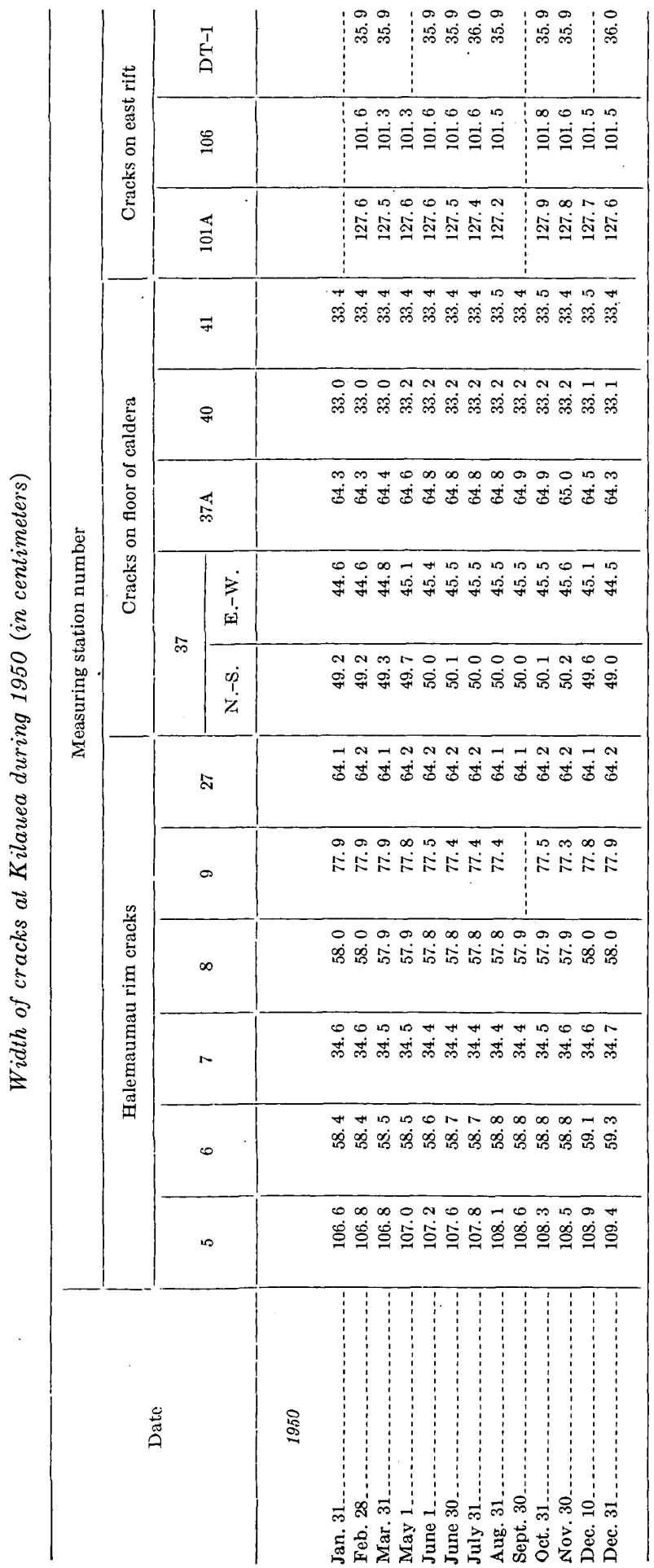


9 millimeters. The southern portion of the crack, stations 7 to 9 , showed little or no measureable widening. The crack at station 27 on the southern rim of Halemaumau also showed no essential change.

The cracks at stations 37 and $37 \mathrm{~A}$, on the floor of Kilauea caldera southeast of Halemaumau, showed net widenings of 10 and 7 millimeters respectively from December 30, 1949, to November 30, 1950. During the earthquake swarm and subsidence of the summit of Kilauea in December, however, the two cracks showed marked closings of 12 and 7 millimeters respectively. The cracks at stations 40 and 4.1, also on the caldera floor but south and west of Halemaumau, showed essentially no changes through the year.

The crack at station $101 \mathrm{~A}$, on the east rift zone of Kilauea near the Chain of Craters road, closed 4 millimeters between February 28 and August 31, suddenly opened 7 millimeters between August 31 and October 31, then closed 3 millimeters by the end of the year. The crack at station 106 also showed a sudden opening of 3 millimeters during September and October, then closed again 3 millimeters by the end of December.

\section{GEOMAGNETIC OBSERVATIONS}

For several years the staff of the Volcano Observatory had wanted to start geomagnetic measurements at Kilauea and Mauna Loa. During January 1950, two Wolfson vertical magnetometers were made available by the Geophysics Branch of the Geological Survey. H. R. Joesting, J. H. Swartz, and R. E. Wilcox spent the first 3 weeks of February at the Observatory setting up instrumental procedures, calibrating instruments, and instructing Observatory personnel in their use.

A series of 29 permanent observation stations was established during February and March on Kilauea and the adjacent slope of Mauna Loa. Observations of the intensity of the vertical component of the earth's magnetic field have been made at each of these stations approximately once a month through the remainder of 1950 .

It is as yet too soon to attempt to evaluate the results of these measurements. A description of the magnetic program and a summary of its results to date will be given in the next annual report.

\section{TEMPERATURE MEASUREMENTS}

Measurements of the temperature of steam escaping from the drilled well at Sulphur Bank were continued at approximately monthly intervals through 1950 . On January 16 the temperature was $95.5^{\circ} \mathrm{C}$., the same as that during December 1949. The temperature remained the same throughout the year except for a measurement of $96^{\circ}$ on September 1 and a questionable measurement of $94.5^{\circ}$ on March 28 . 
Temperature measurements of the live lavas during the June eruption of Mauna Loa are described in the section on the eruption. In summary, temperatures of $1050^{\circ}$ to $1100^{\circ} \mathrm{C}$. were measured on the fluid lava at and close to the vents, temperatures up to about $1130^{\circ}$ in the glowing throat of a spatter cone, $860^{\circ}$ to $1000^{\circ}$ on active lava 10 miles from the vents, and approximately $700^{\circ}$ on immobile lava. These temperatures are $20^{\circ}$ higher than the actual pyrometer readings, to correct approximately for the coefficient of light absorption of gray bodies:

On November 18, approximately 5 months after the end of the eruption, secondary fumaroles on the Kaapuna flow near the road gave temperature readings up to about $400^{\circ} \mathrm{C}$. at depths of 12 to 18 inches below the surface.

\section{THERMAL WATER ON KILAUEA VOLCANO}

Many steaming fissures are present in and about Kilauea caldera. Three other steaming areas are located on the east rift zone of Kilauea volcano northwest of Kokoolau Crater, at Aloi Crater, and in and near Makaopuhi Crater. A few weak steam jets are known on the southwest rift zone. For the most part the steam contains no other gases and appears to represent merely ground water of meteoric origin that has been heated to or slightly above the boiling point by contact with bodies of hot rock.

At Sulphur Bank, situated at the northeastern edge of Kilauea caldera, and at the nearly buried solfataric area east-southeast of Halemaumau, the steam is mixed with a little sulfur gas and carbon dioxide, which are believed to be of magmatic origin. Gas samples collected at Sulphur Bank in August 1922 were analyzed by E. 'T. Allen. The samples consisted of steam, 96.2 percent; fixed gases, 3.7 percent; $\mathrm{SO}_{2}, 0.096$ percent; $\mathrm{S}, 0.004$ percent; $\mathrm{HCl}$, a trace (Allen, 1922). Studies during 1938 to 1940 by S. S. Ballard and J. H. Payne demonstrated that Allen's "fixed gases" probably were air and $\mathrm{CO}_{2}$. Ballard's and Payne's samples consisted predominantly of steam; the remainder consisted of 85 to 98 percent $\mathrm{CO}_{2}, 1$ to 15 percent $\mathrm{SO}_{2}$, and approximately 1 percent air. $\mathrm{H}_{2} \mathrm{~S}$ appeared in samples on March 14, 1940, just before the eruption of Mauna Loa and was present in the collections made during April, but absent in collections made in May and June 1940 (Payne and Ballard, 1940).

In addition to the steam vents at Kilauea caldera, there are five known occurrences of warm water on Kilauea volcano. The localities are shown in figure 2. One occurrence of warm water has been reported in a crack near Waiwelawela Point, 12 miles east of Pahala (Stearns and Clark, 1930, p. 190), but no measurement is known of 
the temperature of the water at that locality. The warm water undoubtedly results from heating of basal ground water by contact with bodies of hot intrusive rock or with hot gases rising from them along the southwest rift zone of Kilauea.

The other four occurrences of warm water are all in the eastern Puna District, on or near the east rift zone of Kilauea. One of these, the well-known "Warm Spring" near the northern base of Puu Kukae, about 0.8 mile eastnortheast of Kapoho, is basal ground water. It forms a pool in a crack at the foot of a small fault scarp, which marks the southern edge of a small graben. Brigham (1868, p. 374) reported that in 1864 this pool (called by him the "Blue Grotto") had a temperature of $90^{\circ} \mathrm{F}$. At present the temperature is only a little above the average air temperature. Measurements on January 11, 1950, gave a water temperature of $84^{\circ} \mathrm{F}$., and an air temperature of $79^{\circ}$.

Another pool of warm water is situated half a mile northwest of that just described and within the same graben. The water is in a crack at the back of a shallow cave, the entrance of which is at the base of a low, northward-facing fault scarp about 750 feet south of a higher fault scarp that marks the northern edge of the graben. 'The locality is about 0.6 mile north of the highway junction at Kapoho and 0.2 mile east of the Kapoho-Koae road. At one time the water was bottled for sale, under the trade-mark, "Volcano Water." The temperature of the water is only a little above that of the air outside the cave. On January 11, 1950, the water temperature was $83^{\circ} \mathrm{F}$., and the temperature of the air in the cave was $77^{\circ} \mathrm{F}$.

The fourth occurrence of warm water is at Pohoiki, about 3 miles south of Kapoho. There basal springs issue just above sea level from a cobble beach at the head of a small bay. The springs are within the zone of splash from the ocean waves, and are distinctly brackish. On January 11 the water temperature was $91^{\circ} \mathrm{F}$. and the air temperature $77^{\circ} \mathrm{F}$.

Warm water is also reported in a lava tube at Opihikao, 6 miles south of Kapoho; but this locality has not been examined by the writers.

No other warm springs are known on the island of Hawaii, although. steam issues from vents in the caldera of Mauna Loa, as well as in that of Kilauea, and along the rift zones of both volcanoes. At first glance the amount of warm water seems surprisingly small in view of the large amount of volcanic heat undoubtedly still present beneath the surface. However, because of the high permeability of the rocks, as Stearns and Clark (1930, p. 190) have pointed out, most juvenile and meteoric hot waters probably become diluted and cooled at the basal water table and do not reach the surface. 


\section{RAINFALL RECORDS}

A rain gage established in October 1948 near the Uwekahuna seismograph station has been read daily through 1950. The daily record is on file at the Volcano Observatory. A gage near the southeastern rim of Halemaumau and another at an altitude of 5,500 feet on the Mauna Loa truck trail have been read once a month. The readings at the Halemaumau gage are published regularly by the U. S. Weather Bureau; those of the Uwekahuna and truck trail gages are not published elsewhere. The monthly totals at the two gages are given in the following table.

Monthly rainfall (inches) during 1950

\begin{tabular}{|c|c|c|c|c|c|}
\hline Month & $\begin{array}{l}\text { Uwekahuna } \\
\text { (4,040 feet } \\
\text { altitude) }\end{array}$ & $\begin{array}{l}\text { Mauna Loa } \\
\text { truek trail } \\
(5,500 \text { feet alti- } \\
\text { tude })\end{array}$ & Month & $\begin{array}{l}\text { Uwekahuna } \\
\text { (4.040 feet } \\
\text { altitude) }\end{array}$ & $\begin{array}{l}\text { Mauna Loa } \\
\text { truek trail } \\
(5,500 \text { feet alti- } \\
\text { tude })\end{array}$ \\
\hline January _.. & 13. 08 & 7. 82 & August_....... & 3. 68 & 3. 04 \\
\hline February & 12. 24 & 1.0. 96 & September_... & .75 & 1. 35 \\
\hline March _. . & 3. 25 & 2. 56 & October & 1. 90 & 4. 29 \\
\hline April..... & 8.51 & 9. 26 & November... & 16. 39 & 9.80 \\
\hline May ...... & 2. 93 & 1. 56 & December.... & 3.01 & 1. 50 \\
\hline June $\ldots \ldots$ & 1. 15 & .27 & & & \\
\hline July _.... & 2. 39 & 3. 64 & Total & 69.28 & 56.05 \\
\hline
\end{tabular}

VOLCANIC CONDITIONS DURING 1950

The year commenced with both Kilauea and Mauna Loa inactive except for the usual steam vents and solfataras. The last eruption of Kilauea had been nearly 16 years before, in September 1934. In contrast, Mauna Loa had been in eruption for five months of the previous year, lava extrusion ending about June 1. Pronounced steaming at Halemaumau following heavy rains on January 10 and November 15 to 17 gave evidence that in spite of the long period of quiescence the thick lava fill formed by eruptions in the crater between 1924 and 1934 was still hot.

During January southward tilting at the Whitney Laboratory on the northeastern rim of Kilauea caldera was distinctly in excess of the normal rate at that season. It appears to have been caused by a reduction of volcanic pressure beneath Kilauea caldera. The reversal to northward tilting took place in early February, nearly two months earlier than the average reversal date, suggesting a change from decrease to increase of volcanic pressure. In early March a reversal from westward to eastward tilting three to four months before the usual reversal suggested an increase of pressure under Mauna Loa. In late March the northward tilting resulting from pressure increase 
beneath Kilauea became strong and continued at an average rate greater than the normal until the 29th of May. Following the heavy earthquake of that afternoon, the ground tilted sharply southward and westward.

On June 1 began a great eruption of Mauna Loa. Although voluminous, the eruption was short, ending about June 23. From June 1 to June 14 during the eruption there was a marked variation of pressure beneath Mauna Loa, shown by a strong oscillation of east-west tilt. On June 5 pressure commenced building up again beneath Kilauea, and by June 1.5 the north-south tilt-curve (fig. 4) had gained a position on the projected trend for the period preceding the Mauna Loa eruption. During the remainder of June and early July, northward tilting was at a rate approximately normal for that season; but from July 23 to August 13 accelerated northward tilting again indicated an increase of pressure beneath Kilauea. This tilting was accompanied by more than 300 earthquakes from shallow foci beneath the northern end of Kilauea caldera. On August 2 the Bosch-Omori seismograph recorded 241 earthquakes.

Northward tilting was at about the normal seasonal rate until early December. During September eastward tilting was less than usual, probably because of a small pressure decrease beneath Mauna Loa; but this was followed by an apparent increase of pressure causing faster than usual eastward tilting in early November. Twenty minutes of continuous volcanic tremor on November 17 appears to have indicated the movement of magma at depth under Kilauea. Early in December came the big collapse at Kilauea, accompanied by rapid southwestward tilting at the Whitney station (see p. 82).

Fume continued along the southwest rift of Mauna Loa until the end of the year. Varying atmospheric conditions and strength of wind caused the fume to be more conspicuous on some days than on others. On September 29 and 30 large steam and fume clouds developed over the 1950 vents following heavy rains, giving rise to false reports of an eruption. The year closed with both volcanoes quiet.

\section{THE 1950 ERUPTION OF MAUNA LOA}

The 1949 summit eruption of Mauna Loa came to an end about June 1 (Macdonald and Orr, 1950). Lack of westward tilting after the eruption indicated that the magma pressure remained high and the molten lava probably continued to stand high in the conduit. A moderate release of fume continued in the summit caldera throughout the remainder of 1949 and the spring of 1950. A normal amount of eastward ground tilting was recorded at the Volcano Observatory during the fall of 1949 , but during the spring of 1950 westward tilting was markedly less than usual, indicating a tumescence of the moun- 
tain. On the basis of past history, the summit eruption was expected to be followed by a flank eruption probably within 2 years, and the high position of the magma column suggested that the interval might well be shorter. During May many earthquakes originated at Mauna Loa and pointed to a distinct uneasiness of the volcano. 'These culminated on May 29 with a strong earthquake originating on the southwest rift near the summit. In a bulletin released by the Volcano Observatory and published in newspapers on May 30, Finch called attention to the unrest of the southwest rift of Mauna Loa and stated that if the eruption rame soon it would take place there. The eruption came on the evening of June 1, 1950.

\section{NARRATIVE OF THE ERUPTION}

On the evening of June 1, 1950, Mauna Loa volcano erupted from vents along its southwest rift zone. Glow was first seen from the Volcano House at about $9: 25$ p. m., but, as the seismograph registered harmonic tremor starting at 9:04 p. m., it is probable that the eruption actually started then or very shortly afterward. About 9:10 p. m. Mr. and Mrs. Alfred Hansen, in Naalehu (fig. 2), heard a deep rumbling from the direction of the top of the mountain.

The first outbreak was high on the rift. At first two narrow, illuminated columns of fume were visible, but these rapidly expanded down the mountain slope. A fissure 2.5 miles long opened from about 12,600 to 11,000 feet altitude, with its upper end close to the small pit crater Lua Hou (fig. 5 and pl. 1). From this fissure poured large volumes of fume, rising in a narrow column about two miles into the air, then spreading laterally to form a mushroom-shaped cloud, brightly illuminated by the glare of the incandescent lava beneath. A flood of fluid, gas-rich lava poured from the fissure and headed westward down the mountain-side (fig. 6). Many short flows were formed, and one long flow (flow 2, fig. 5 and pl. 1) extended downslope about 5 miles to an altitude of about 9,000 feet. Robert Duncan, of Pahala, reported hearing the roar of the lava fountains about 15.5 miles away, at the junction of the Kapapala Ranch road with the highway.

The outbreak at the upper source lasted only a few hours. By $12: 30$ a. $\mathrm{m}$. on June 2 the glow at the upper source was distinctly less, and by 1:30 a. m. it was feeble. At that time the activity at the upper source had diminished greatly and may already have been finished.

At 10:15 p. m. on June 1 observers at the Volcano Observatory and along the highway between Kilauea caldera and Pahala (fig. 2) noticed a small puff of fume rising from a point on the rift at about 8,250 feet altitude, approximately 8 miles southwest of the lower end 


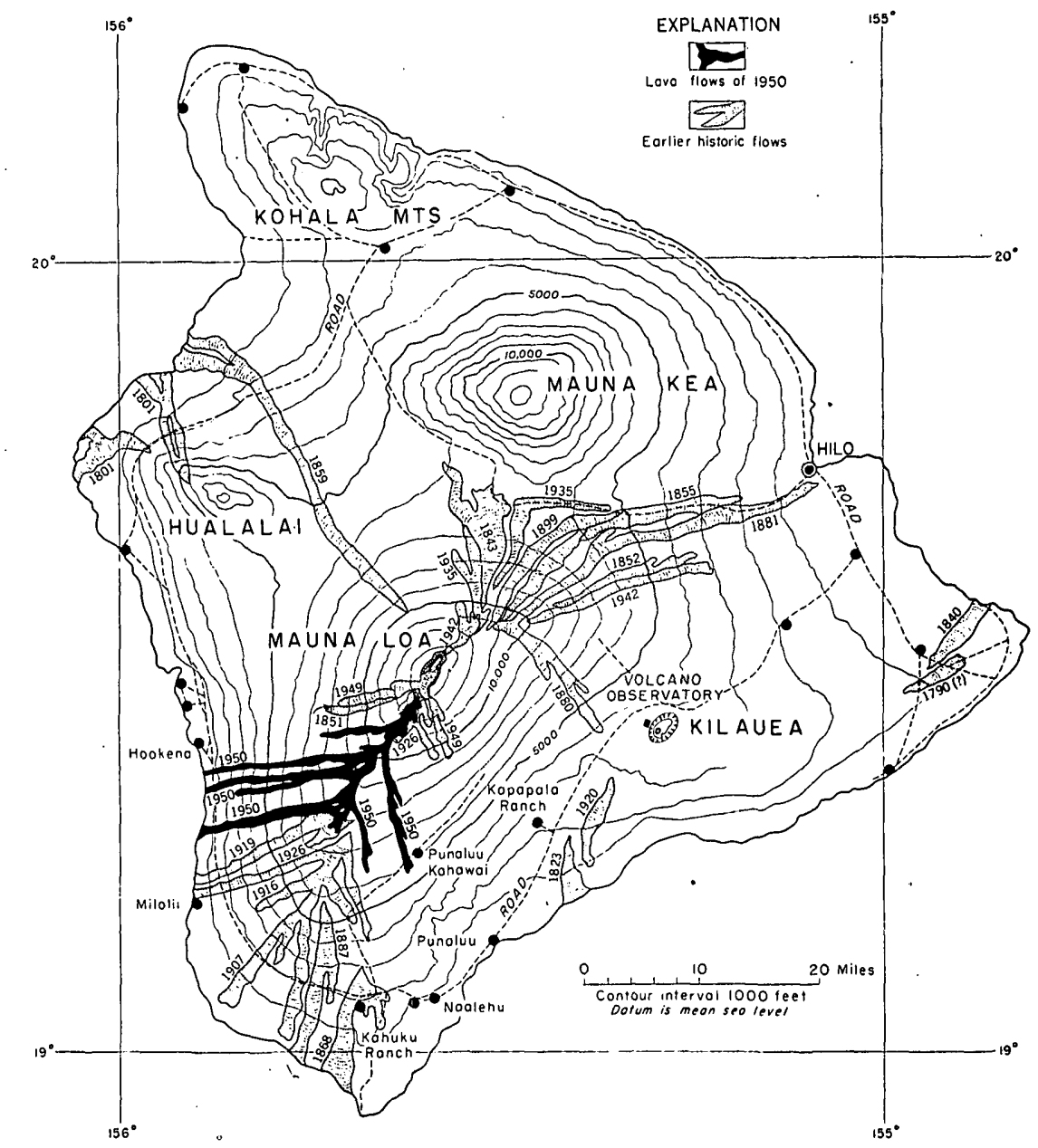

Fifire 5.- Map of the island of Hawaii, showing location of lava flows of the 1950 eruption of Mauna $!$ oR. in relation to the flows of 1949 and earlier historic flows.

of the glowing fume column at the upper source. At 10:23 p. m. bright glow appeared on the lower fume cloud, indicating that fluid lava had reached the surface. The illuminated fume column rapidly spread as the length of the erupting fissure increased. Margaret Finch, watching from the Volcano Observatory, observed the glow expanding up the mountain, which suggested that the fissure in the lower vent area may have opened upslope. However, the sequence of flows described on the following pages indicates clearly that the site of principal lava extrusion shifted progressively down the slope.

The glow from the lower source continued to increase rapidly, but by 10:45 p. m. it was obscured by clouds. Lava fountain activity was very strong. At 11:40 Finch and Macdonald could hear the roar 


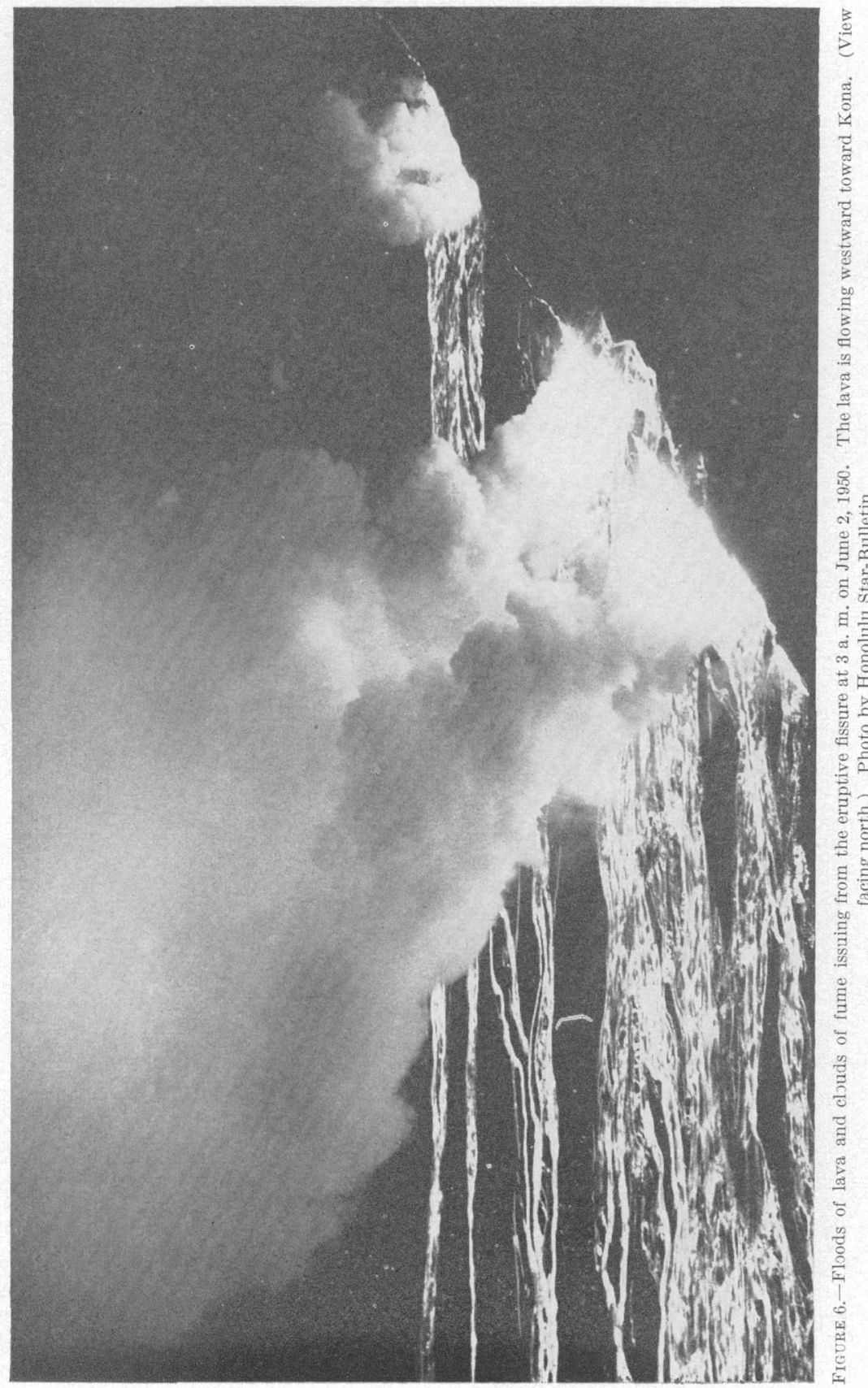


of the lower fountains distinctly at the point where the highway crosses the western branch of the 1907 lava flow, nearly 15 miles from the site of the eruption.

Early on the morning of June 2 the activity was observed from the air by Frank Hjort. He reported lava fountains issuing from a line of fissures about 6 miles long, extending from about 10,500 to 8,500 feet altitude. Another erupting fissure, nearly two miles long, lay in echelon with the main fissure and about 0.7 mile southeast of it, extending from about 8,200 to 7,800 feet altitude. Between the main line of fissuring and the shorter easterly line a broad pond of molten lava had accumulated. Floods of very fluid lava were pouring westward in a series of anastomosing streams (figs. 6 and 7). Lava from the principal fissure was pouring over the shorter westerly fissure partly drowning it. Sulfur dioxide fumes were very strong. About noon Ross Bender flew over the source area and reported two principal lines of lava fountains playing along fissures at approximately 10,000 and 8,500 feet altitude. The source at 10,000 feet was largely obscured by fume, but no lava movement was observed there or in the flows originating there. From the source at 8,500 feet, great floods of lava were pouring westward. At the time of his first observations, lava fountains were playing from several isolated stretches of the fissure below 9,000 feet; but, while he watched, the activity increased and fountains developed along the intervening portions of the fissure, making the curtain of fountains essentially continuous. Some of the fountains he estimated to be about 300 feet high (fig. 8).

A similar condition was reported on the afternoon of June 3 , when Frank Oberhansley, I. J. Castro, and Herbert Quick flew over the scene of activity. The lava fountains formed an almost continuous "curtain of fire," averaging from 150 to 200 feet high, with some of the bursts reaching 300 feet or even more.

The line of fissures forming the lower source was not continuous. Over a stretch of about 2.5 miles, between 8,950 feet and 9,750 altitude, there appears to have been no lava liberation. Between 9,750 and 10,500 feet altitude there was a line of active fountains 1.6 miles long. Below 8,950 feet altitude there was a series of nearly aligned fissures in echelon and commonly slightly overlapping.

During the first few hours of the eruption, two very rapid flows poured from the vent area above 9,000 feet altitude. One of these (flow 5, pl. 1) issued from the rift between 10,000 and 11,000 feet altitude and advanced south-southeastward in the general direction of Punaluu. By daybreak on June 2 it had passed the ranch road a short distance west of Punaluu Kahawai. On the morning of June 2 , it was examined from the air by L. W. Bryan. At that time it had 


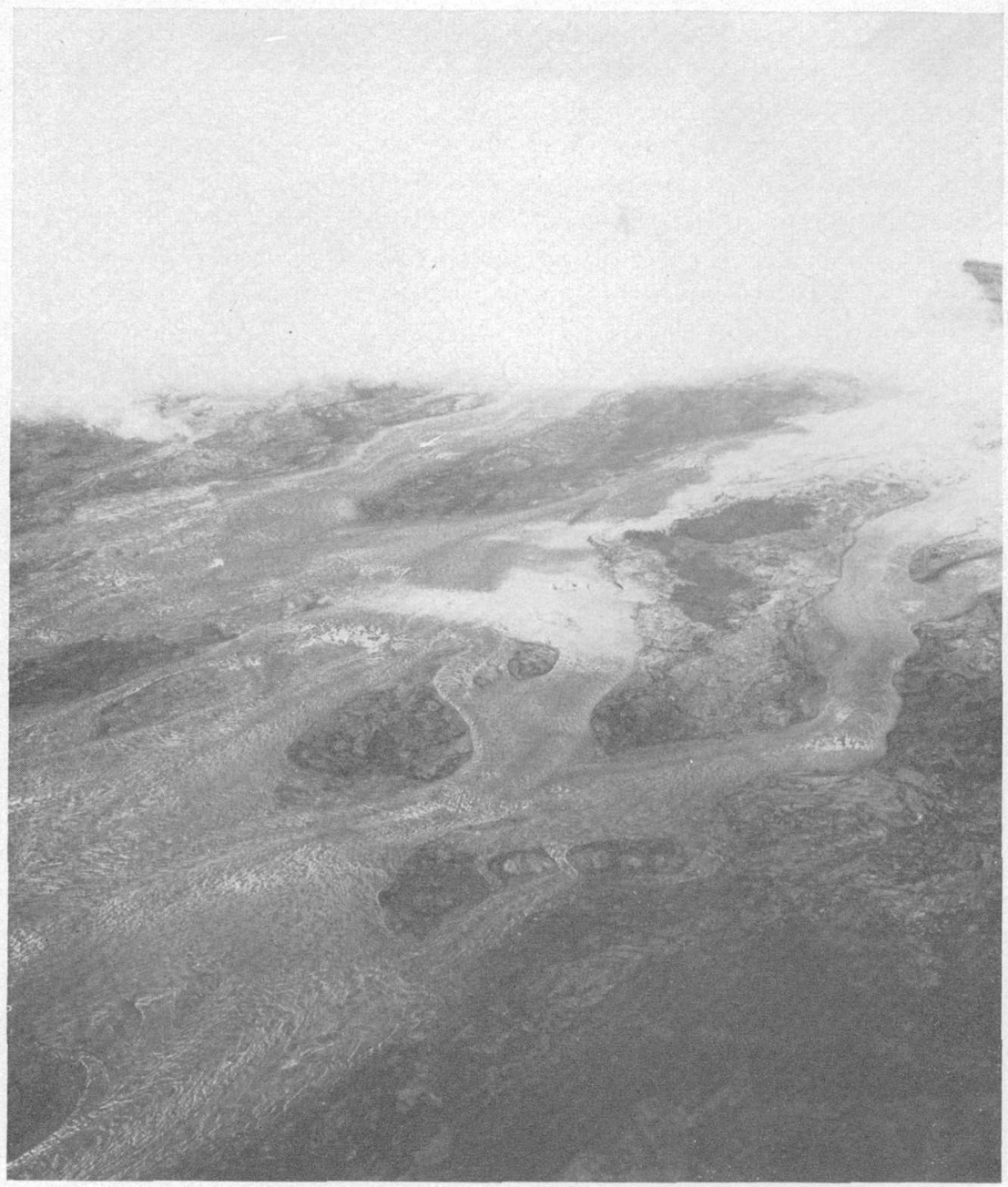

Figure 7.-Braided lava streams flowing westward near the active rift on the morning of June 2, 1950 (Facing northeast.) Official photograph, Fleet Air Photographic Laboratory Utility Squadron 7. U. S. Navy.

reached an altitude of about 5,500 feet, approximately 10 miles from its source; but its advance appeared to be essentially over.

The other flow (flow 3, fig. 1) originated lower on the rift, between 9,000 and 10,000 feet altitude, and moved rapidly westward. At $12: 20$ p. m. it was less than a mile above the highway, and Ruth Macdonald reported that the roar and explosions caused by the lava advancing through the forest were clearly audible and the glare from hot lava and burning vegetation was strong. The portion of the flow near the vents was pahoehoe, but the portion on the lower slopes of the mountain was aa. The flow crossed the highway at about $12: 30$ 


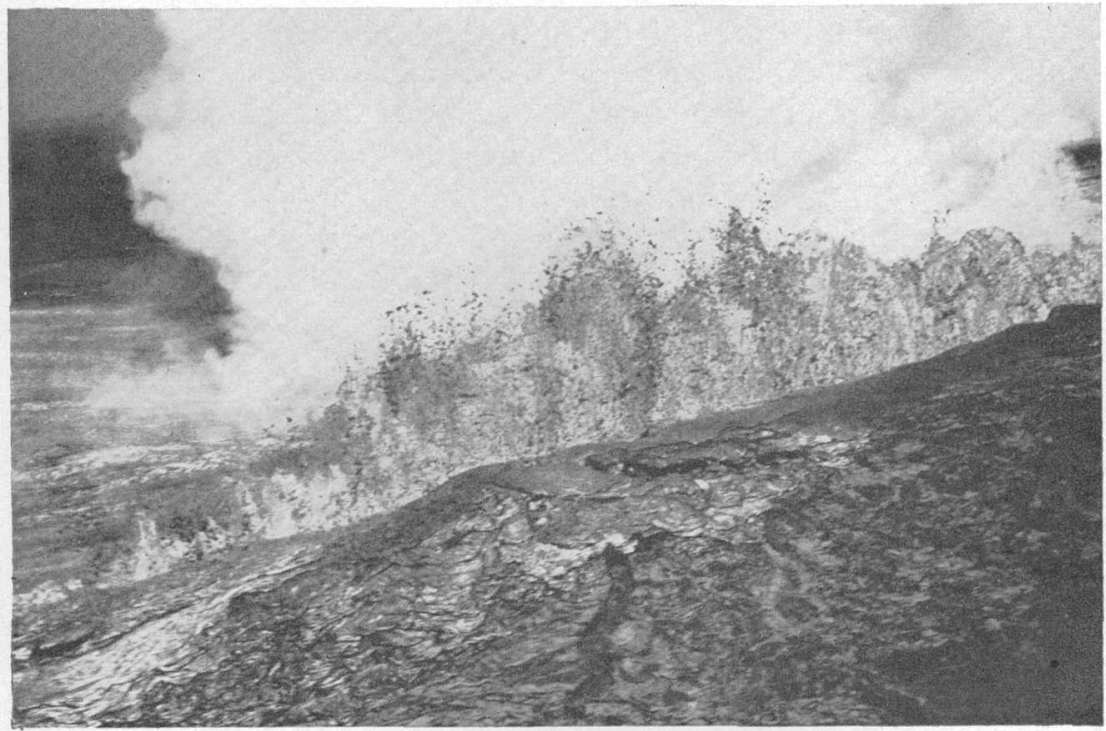

FigURe 8.-Lava fountains as much as 250 feet high playing along part of the fissure on the morning of June 2, 1950. Official photograph, Fleet Air Photographic Laboratory Utility Squadron 7, U. S. Navy.

p. m. destroying several houses, a filling station, and the Hookena Post Office at the village of Pahoehoe (pl. 1). There was a light but steady fall of fine black ash and some Pele's hair mixed with rain. The flow reached the sea, 0.8 mile west of the highway, at about 1:05 a. $\mathrm{m}$. on June 2 , having covered its 15 mile course down the mountainside at an average rate of 5.8 miles an hour. Where the hot lava entered the sea, a great billowing cloud of steam arose. However, observers reported no apparent increase in the amount of ash in the air. This first flow to reach the sea has been termed the Honokua flow, because the course of the flow lies largely in the Honokua land division.

In an earlier report (Finch and Macdonald, 1950) the flow was termed the "Hookena" flow. Since then, however, the Hawaii Visitors' Bureau has officially adopted the name Honokua flow, and the latter name is accepted in this report. Similarly, the names "Magoon Ranch" flow and "Ohia Lodge" flow, used in the earlier report, have respectively been replaced by the new official names Kaohe flow and Kaapuna flow.

By daylight the lava movement in the Honokua flow had greatly diminished. By 11:00 a. m. it had practically ceased, and only a little steam was rising where the flow entered the ocean.

Shortly after the beginning of the Honokua flow, another flow started westward from the rift between 9,000 and 8,500 feet altitude. 
The new flow (flow 4, pl. 1) crossed the highway at the Magoon Ranch house, 1.2 miles south of the earlier Honokua flow, at about 5:00 a. m. on June 2. The ranch house was destroyed, as were two or three other houses. The flow has been named the Kaohe flow.

The Kaohe flów was aa in character. Along the highway just south of the main ranch house the advance of the lava was checked by a loose stone wall, about 3 feet high. The lava eventually piled up enough to spill over the wall, but it does not appear to have seriously damaged the wall, and for a distance of about 250 feet it spread only. 15 to 20 feet beyond the wall. Farther north the flow continued unchecked down the mountainside, destroying a coconut grove and another house. It entered the sea at 12:04 p. m.

For about an hour and a half before it reached the ocean, the advance of the flow was observed by Macdonald and B. J. Loucks. By that time the lava had lost its initial great fluidity and was creeping ahead at a rate of only about 750 feet an hour. The flow was descending a steep slope half a mile inland and spreading out as a broad fan over the flat sparsely vegetated terrain near the coast. As the edge of the flow engulfed the few large trees, there were minor explosions with flashes of flame. Occasionally similar roars and flashes came from the central part of the flow, probably from tree trunks buried in the flow. Many tree trunks were carried down with the flow, some of them riding along on the flow surface or projecting upward from it, flaming like torches.

At 11:30 a. $\mathrm{m}$. the volume of lava in the flow suddenly increased, and a new flood of lava moved out over the older, still-moving flow on the steep slope below the highway. At the base of the slope, the new aa front spread out fanwise over the older lava, flowing at about twice the speed of the earlier front, which was still advancing. At 12:04 p. m. the first front entered the ocean, and a huge column of steam arose in great billows with a counterclockwise, corkscrew motion. No sign of ash being thrown up where the flow entered the sea could be seen. At 12:10 the second gush of lava reached the sea. The steam column increased but there was still no evidence of any strong explosive action or any appreciable amount of ash being thrown up. In the meantime the constant light fall of fine black ash, with some Pele's hair, continued as it had all morning.

By the afternoon of June 3 movement in the Kaohe flow at the highway appeared to have largely ceased, although the column of steam rising where the flow entered the ocean appeared strong.

A smaller finger of lava, which reached 2,700 feet altitude just south of the Kaohe flow, appears to have branched from the Kaohe flow during the early hours of June 2 . 
Another major flow apparently started late on the night of June 1 and advanced westward south of the Kaohe flow. This flow (flow 6, pl. 1) has been.called the Kaapuna flow. It originated at the lower line of fissures between 7,800 and 8,800 feet altitude. At 12:20 p. m. on June 2 Macdonald and Loucks were with a police detail and a small group of refugees at Ohia Lodge awaiting developments from this new flow, which was known to be advancing through the forest a short distance above the road (fig. 9). Because of the large amount of smoke and fume combined with a low cloud cover, visibility was very poor, and the exact location of the flow front was unknown. About 12:30 a patroling National Guard plane flew over at very low altitude and dropped two "Mae West" life jackets to which were attached warnings to leave immediately for the southward. These instructions were carried out.

At approximately 2 p. m. the Kaapuna flow reached the highway about a quarter of a mile south of Ohia Lodge and 4 miles south of the Kaohe flow. At about 3:30 p. m. the Kaapuna flow entered the ocean just north of Heku Point, having taken an hour and a half to cover the 1.3 miles from the road to the sea. A great billowing cloud of steam arose with a counterclockwise movement (fig. 10), but again there was no sign of violent explosion or formation of any appreciable amount of ash where the lava entered the sea.

By 5 p. m. a line of steaming water, marking the subsea course of the lava, extended out to sea for about half a mile from the point where the Kaapuna flow entered the ocean. Close to the shore and directly over the submerged flow the water was boiling; and a semicircular area of hot, turbulent water extended for a mile offshore. Many fish, killed by the hot water, were seen drifting or washed up on shore during the next few days. The hot water drifted southward with the prevailing currents. Many charred logs, the remains of tree trunks carried down on top of the flows, were seen in the water off Hoopuloa, 5 miles south of the point where the Kaapuna flow entered the sea.

At 4: 00 p. m. the Kaapuna flow was about 750 feet wide and 10 feet thick at the highway. Its outer edges were slowly-moving fields of aa, creeping along at a rate of only a few feet an hour. Near its center there appeared to be a narrow, more rapidly moving lava river, but visibility was very poor and the edge of the flow was still too hot to climb. The flow was still spreading a little laterally. Occasionally trees were pushed over at the edge of the flow, and others burst into flame while they were still standing, as the heat from the lava dried out the foliage. Minor explosions were heard from time to time as trees were engulfed in hot lava and the water in their tissues suddenly was transformed into steam. 


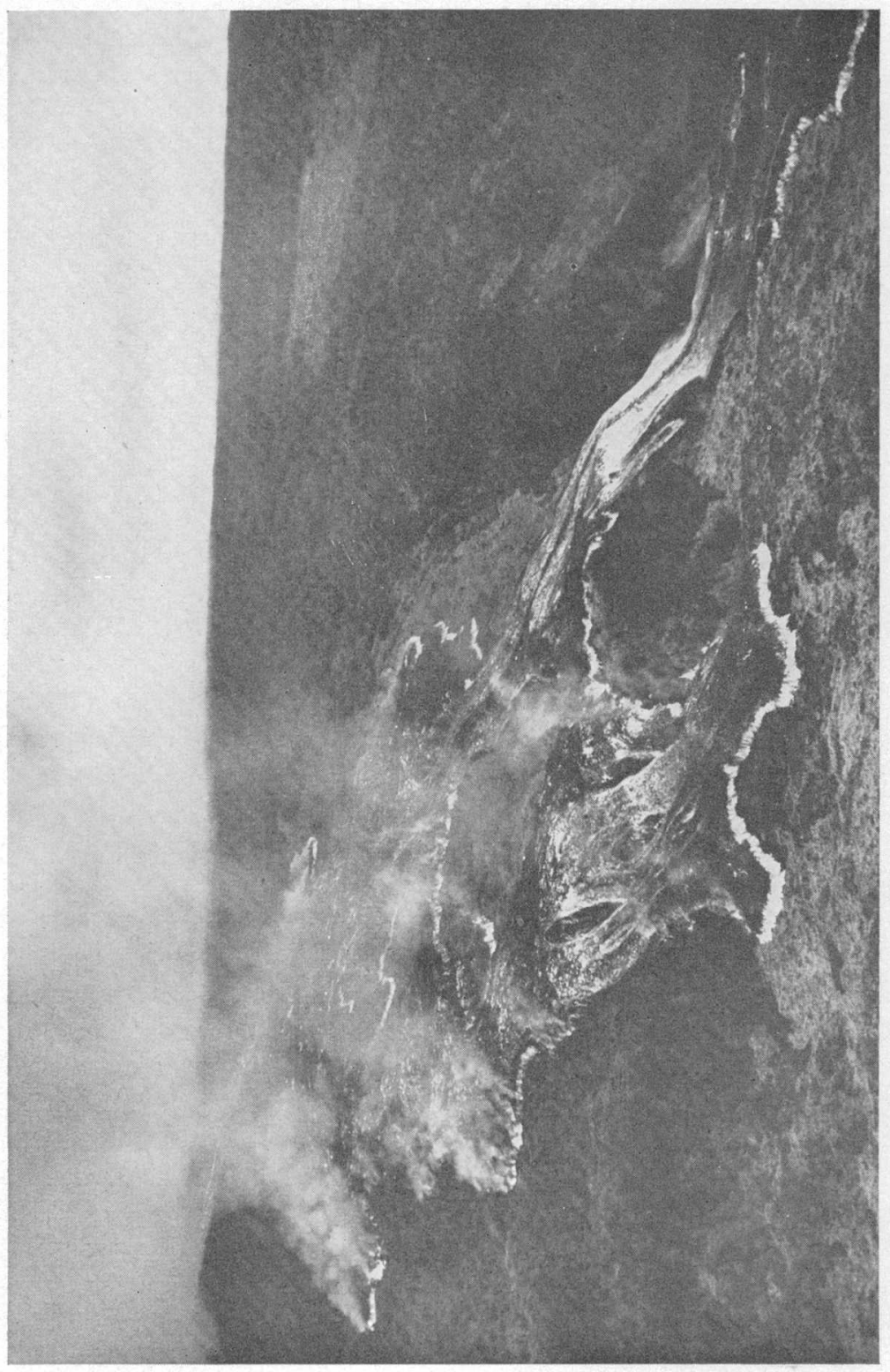

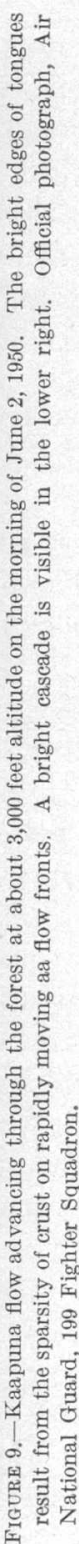



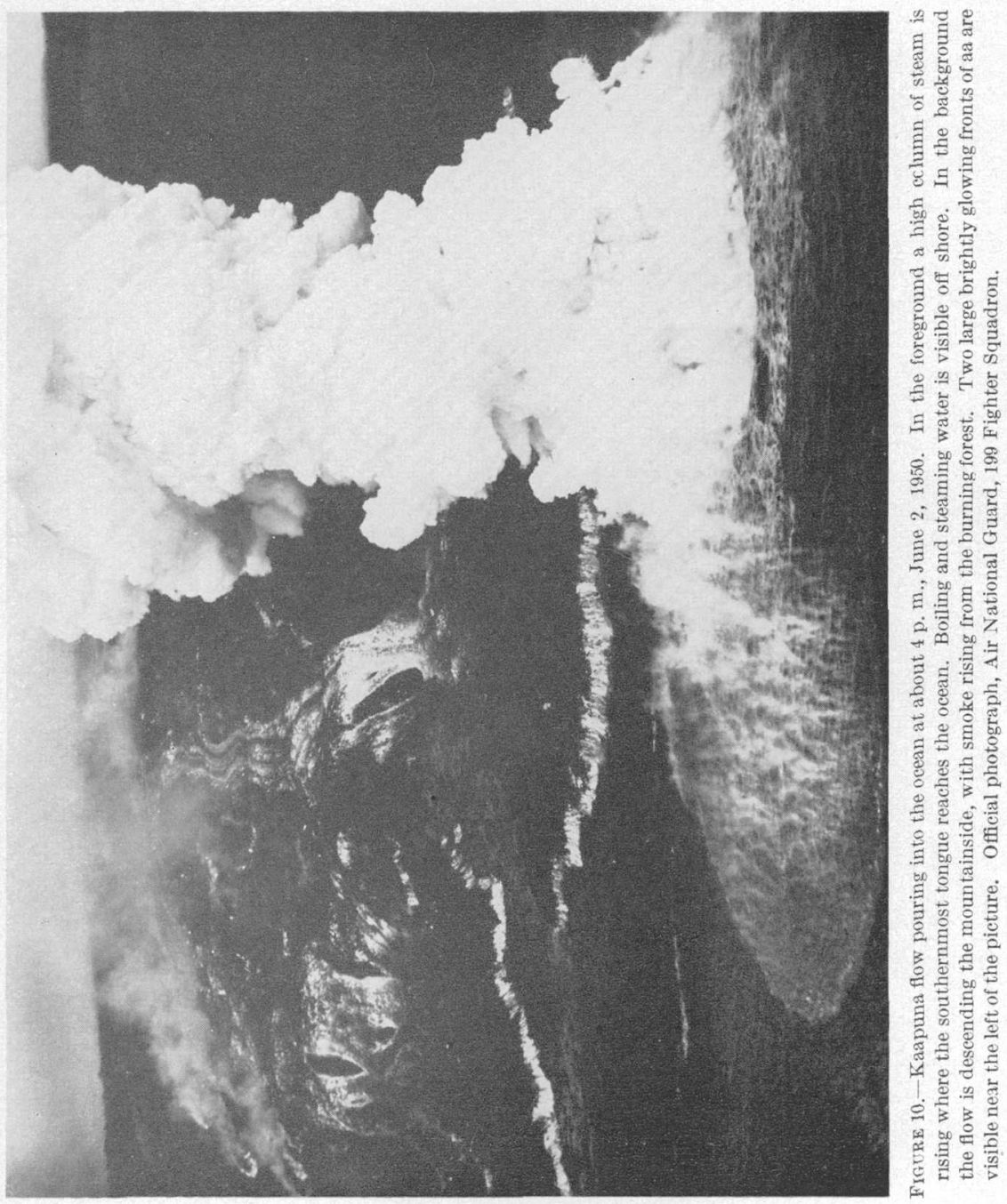
The odor of hydrocarbon gas, probably largely methane, was strong, and the flow smelled much like a leaking gas stove. Yellow flames issuing from the lava were common along the edges and top of the flow, and there were also many blue flames resembling that of a welladjusted gas burner. These gases undoubtedly were derived by the destructive distillation of the vegetation buried and engulfed by the lava (Finch, 1926). Many flames burned at cracks in the old lava, commonly 10 to 15 feet and rarely as much as 50 feet or more from the edge of the new flow. Some of these flames burned steadily, but many went out periodically at the surface, only to reignite within the crack and burst out again at the surface with a loud "whoomp!" Some of these gas ignitions were explosively violent, throwing rock fragments several feet.

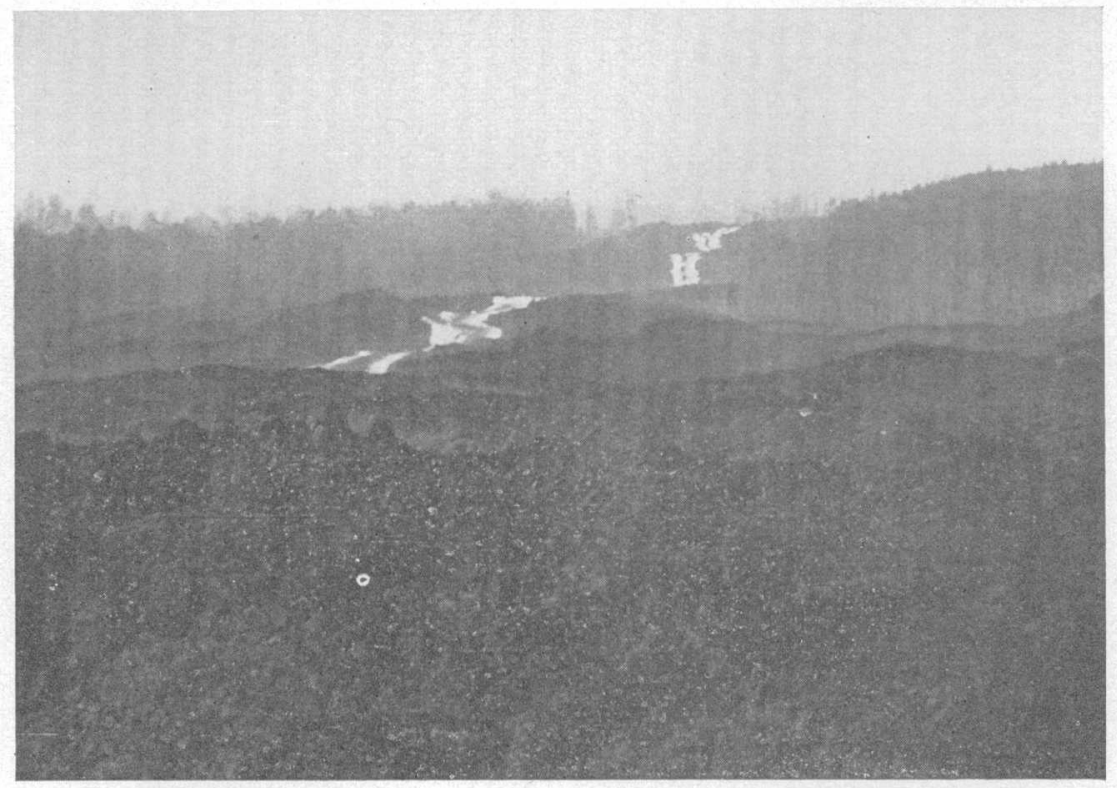

FIGURE 11.-View looking inland along the Kaapuna flow from a point near the highway, on the eyening of June 2, 1950, showing the lava river in the midst of a field of slowing moving aa. The aa in the foreground is part of the new flow and was still very hot when the photograph was taken.

Along the edge of the flow the vegetation was partly broken, leaves partly blown off of trees, and leaves of ti plants shredded and broken off. Most of the breaking appeared to have been caused by blasts of hot air and gas from the direction of the flow. These were probably in part marginal explosions caused by ignition of hydrocarbon gases, but some of the damage was observed to be caused by the small but strong whirlwinds which formed over the flow and moved across it. 
At 6:00 p. m. it was possible to climb the edge of the flow and go out onto it about 150 feet. Beyond that point the gas and heat were unbearable. Much of the observer's distress was evidently caused by a deficiency of oxygen in the hot air. From the vantage point on the top of the flow, the central lava river could be seen clearly (fig. 11). It was about 25 feet wide. At highway level it was estimated to be flowing 15 miles per hour; but, about half a mile upslope from the highway, there was a broad, double, lava cascade on a steeper slope where the speed was estimated to be 25 miles an hour. 'T'emperature measurements of the river ranged from $860^{\circ}$ to $880^{\circ} \mathrm{C}$. A spectacular feature of the lava river was the many large blocks it carried along. Most were largely incandescent, although a few were largely dark. Some of the blocks were as much as 20 feet high above the surface of the flow, and 30 feet long, although most of them were much smaller. Occasionally large blocks became wedged sideways in the channel causing local overflows. The blocks appeared to have been dragged along by a lower, less rapidly moving, and probally more viscous stratum in the river (Finch, 1943). Some, projecting above the stream surface, could be seen to be moving distinctly less rapidly than the surficial part of the river around them.

Condensation of water in the steam cloud, which rose where the lava entered the sea, caused a continuous rain beneath the cloud. That the rain came from the cloud is shown by the fact that just south of the edge of the cloud there was no rain and the night was fairly clear. There was enough salt in the rain beneath the steam cloud to cause the drops to sting the face and eyes and to form a peculiar thin glaze on automobiles, which was very difficult to remove.

At 12:20 a. m. on June 3 Macdonald and Loucks started down the southern side of the Kaapuna flow from the highway. About half a mile from the ocean, the flow reached the top of a steep slope formed by a buried fault scarp (Stearns and Macdonald, 1946, p. 39), where it divided into three branches. At a point just above the steepening of slope, the speed of the lava in the river was estimated to be about 15 iniles an hour; but, as it cascaded down the buried scarp, the lava reached a speed estimated at 25 to 30 miles an hour. Temperatures on the cascide were as high as $910^{\circ} \mathrm{C}$. On the flatter ground below the scarp the speed of the flow decreased as the lava spread out to form a broad fan about three-quarters of a mile wide. The central lava river was the most active, and formed the largest steam column. The river appeared as a bright orạnge-red streak with long, dark streaks paralleling its edges. The southern river was moving less rapidly, and its surface was largely covired with dark blocks, between which could be seen red glow. 
There was a light but continuous fall of black ash, of sand and silt sizes. Some of this ash may have been formed by steam explosions where the lava entered the sea, but much of it probably was fine debris picked up from the flow by the numerous small whirlwinds which swept over its surface.

Just above the big cascade, half a mile from the ocean, blue or greenish-blue flames were common on the slow-moving margin of the flow, and yellow flames even more frequent. Dancing, pale-blue flames, resembling will-o-the-wisps, occasionally were seen for a few moments as much as 35 to 50 feet above the main lava river and isolated from it with clear air between them and the lava. Some of these were formless, but others looked like fire-balls.

The Kaapuna flow below the highway was examined on the morning of June 3 by D. C. Cox, D. A. Davis, and C. K. Wentworth. At $10: 20 \mathrm{a} . \mathrm{m}$. the condition was much like that of the previous night, but at 10:35 a sudden increase in the volume of lava in the flow was observed. The speed of the lava in the big cascade between the highway and the shore increased notably, and a sheet of more rapidly moving lava appeared to override the older less rapidly flowing sheet. By 11:15 the surge had decreased, and the speed of flow lessened again. Davis estimated the speed in the cascade to be about 20 miles. an hour during the peak of the surge and 5 to 6 miles an hour as the surge abated. During the surge the lava fan at the foot of the cascade had built up appreciably. At 11:30 a. m. after the surge had ceased, the surface of the central part of the fan subsided as the fluid lava underneath drained away, leaving high ridges around its edges. At the ocean an increase in the size of the steam column, some minor explosions along the shore, and pushing up of small lava ridges from the water just offshore indicated lava drainage into the sea. However, observers on the landward side of the fan could see no lava spilling from the other edge of the fan into the sea; hence, the drainage must have been through hidden subterranean passages.

From 1:00 p. m. June 3 until 7:00 a. m. June 4, the Kaapuna flow about 2,000 feet inland from the road was observed by Wentworth, Davis, and Cox. Two streams of lava descended a steep slope in a cascade about half a mile long and reunited to form a single stream before reaching the road. At the foot of the cascade the flow was about 1,000 feet wide. Just north of this main flow another tongue of lava was advancing slowly seaward, burning trees and knocking them over. Optical pyrometer measurements made by Davis and Cox of the surface of the lava river indicated temperatures ranging from $830^{\circ}$ to $960^{\circ} \mathrm{C}$. About 2:00 p. m. the volume and velocity of the main flow commenced to increase. This surge reached its maximum about $2: 30$, after which the volume again decreased. Went- 
worth estimated the volume of actively moving lava in the flow during the surge to be five to ten times as great as that before and after the surge. Similar surges were observed in both channels of the flow at intervals of 65 to 85 minutes during the rest of the afternoon and night. Davis estimated the speed of flow in the main rivers to range from 5 to 20 miles an hour, and angular measurements by Wentworth and Cox during a surge at 11:25 p. m. revealed speeds of 7.8 to 8 miles an hour. The 10- to 25-foot high aa front of each surge advanced with loud clinking and crunching down the lava river channel. During the larger surges, new lava spread from the river over much of the surface of the flow; and directly preceding and during some of the surges, there appeared to be a definite, though small, heating up and inflation of the stationary aa fields at the edges of the flow. This same phenomenon was observed at other times.

During the afternoon of June 4 the Kaapuna flow was watched by Arnold Mason. Conditions remained much the same as on the preceding day. Several surges of lava were observed, the last three at approximately 5:30, 6:00, and 6:30 p. m. When Finch and Cox arrived at $6: 30$ p. m., they found that at the road level the flow had been considerably widened by a new tongue, which had come down parallel to the northern side of the older flow and destroyed the Ohia Lodge. A sluggish lava river in the new tongue was feeding a slowmoving a front just below the road. The entire flow at road level was about a quarter of a mile wide. Another tongue still farther north was advancing slowly through the forest about half a mile above the road. Its presence was revealed by occasional glimpses of glowing lava and by a bright glow from burning vegetation.

Davis returned to the Kaapuna flow above the road about noon on June 5. The width of the flow had increased to approximately 1,500 feet, and the active channels were entirely in the northern part of the flow. The lava was moving much more slowly than on the two preceding days, and the surges were smaller and of shorter duration. The maximum speeds in the lava river's were estimated at 4 to 5 miles an hour. The new tongue north of the main flow was still advancing. Cox and Macdonald returned to the flow at 2:00 p. m. and went out onto the flow about 250 feet. The southern edge of the flow was still hot, but essentially motionless. The northern edge, beyond the river, was moving slowly. The flow as a whole had increased in thickness to an average of 20 to 25 feet. On the flat near the coast the flow had spread about 750 feet farther south than on. June 3 . The coastline had been transformed from a shallow embayment to a slight promontory.

Late in the evening of June 2 or early on June 3 another flow 
(flow 5, pl. 1) started from the vent area at 8,300 feet altitude and moved southward down the mountain slope toward the main buildings of the Kahuku Ranch. This has been named the Kahuku flow. The upper portion of the flow was narrow, from 0.1 to 0.15 mile wide. On June 3 the flow was very active, with a narrow bright red lava river in the middle of a dark streak of aa. On June 4 the flow was still very active and was spreading out to form a front nearly half a mile broad at about 7,200 feet altitude, $3 \frac{1}{2}$ miles from its source. The lava river was reported to be about 100 feet wide. On June 5 Don Campbell reported from aerial observations that the Kahuku flow was still advancing, but appeared to have slowed up. On the morning of June 6, James Beatty reported that its front had reached an altitude of about 6,500 feet. Movement continued through June 6 and the early hours of June 7, bringing the lower end of the flow to approximately 6,300 feet altitude, 5.8 miles from its source. On the afternoon of June 7 , the lower portion of the flow appeared dead, but there was still some movement in the flow near the vents. The flow was completely dead by the morning of June 8 .

Frank Hjort and Ross Bender reached the vent area on the afternoon of June 3 and camped at 8,700 feet altitude near the upper end of the lower line of vents. The fissure near 10,000 feet altitude was fountaining sporadically, but most of the activity was concentrated along the lower fissures below 8,900 feet altitude. From 4:30 to 8:00 p. m. activity on the lower fissures was continuous but varied rythmically in intensity and character. Approximately once an hour an upsurge of activity commenced near the upper end of the fissure and migrated down along the fissure. Each revival of activity started at a large spatter cone at about 8,800 feet altitude with a loud roaring noise much like the exhaust from a steam boiler. This rush of gas was followed by a spray of lava droplets and red-hot cinders. The roaring release of gas migrated downhill along the rift, at some places making noises like thunder or heavy artillery. As the gas release ceased, the fountain activity and amount of lava liberation increased progressively along the rift until it was essentially continuous along the two miles of fissures which were in view. The fountains, rising to heights of about 50 feet, were lower than those earlier in the eruption (fig. 12). This activity gradually abated, and there was a lull of 20 minutes to a half hour duration before the violent gas release started again at the upper end of the fissure, and the cycle was repeated.

Most of the liberated lava poured westward, feeding the Kaapuna flow. A pool of hot lava 0.7 mile long had accumulated on the east side of the rift and spilled southeastward to feed the Kahuku flow. At the head of the Kahuku flow, the lava plunged over the steep slope 


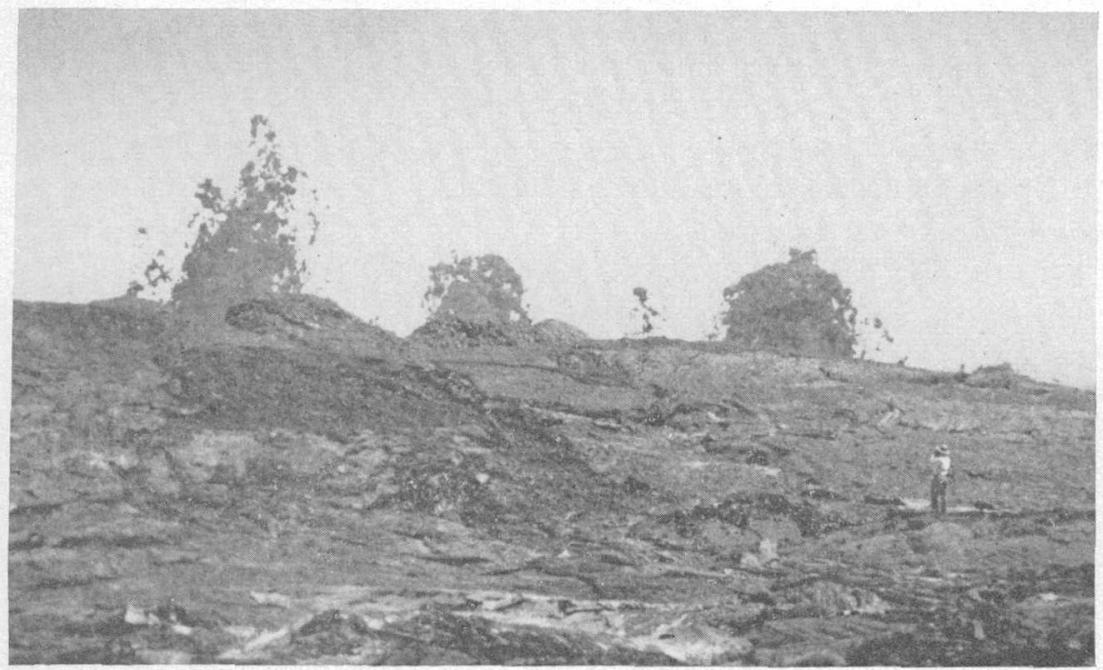

Figure 12.-Lava fountains 30 to 50 feet high at the vents at 9,000 feet altitude on the southwest rift zone of Mauna Loa, June 3, 1950. Hawaii National Park photo by Ross Bender.

of a buried cinder cone making a spectacular double cascade some 500 feet long and 200 feet wide. The rate of flow in the cascade was probably about 35 miles an hour. Near the base of the cascade, the highly fluid lava struck a bump on the channel floor, and the liquid was directed upward and outward into the air. At first view, from a distance, it appeared to Mr. Bender to be a fountain in the river, but on closer inspection its true nature was obvious.

A party composed of Geological Survey and National Park personnel reached the vent area on the afternoon of June 6 . The cascade at the head of the Kahuku flow was still active; but the speed of flow had greatly decreased, not exceeding 10 miles an hour on the steepest slope. Fluctuations in the volume of flowing lava were obvious and came at approximately half-hour intervals. During the night of June 6 , the lava fountains along the rift were low and sporadic. Increases in activity continued to come about every half hour and progressed downslope along the rift. Once the increase in lava output was prereded by a loud blowing noise and shower of incandescent cinder from the large spatter cone at 8,800 feet altitude.

On the morning of June 7, the activity along the rift was still weak. Above 8,600 feet altitude the vents were fuming strongly, but no lava poured out. Below that altitude fountaining continued, but none of the fountains were more than 25 feet high and most were only a few feet.

About 3:00 p. m. Davis, Cox, and Macdonald crossed the still hot pond of shelly pahoehoe which had fed the Kahuku flow and ap- 
proached to within 15 feet of the lava river. At 8,440 feet altitude two branches of the river plunged over a 25 -foot cascade and joined at its foot. Most of the river was moving only 3 or 4 miles an hour and was largely crusted over with a skin of wrinkled and ropy pahoehoe. In the cascade, however, the speed of flow was estimated at 30 miles an hour, and the crust was broken up to reveal the incandescent liquid beneath (fig. 13). Measurements with an optical pyrometer of the hot lava in the cascade yielded temperatures from $1030^{\circ}$ to $1040^{\circ} \mathrm{C}$.

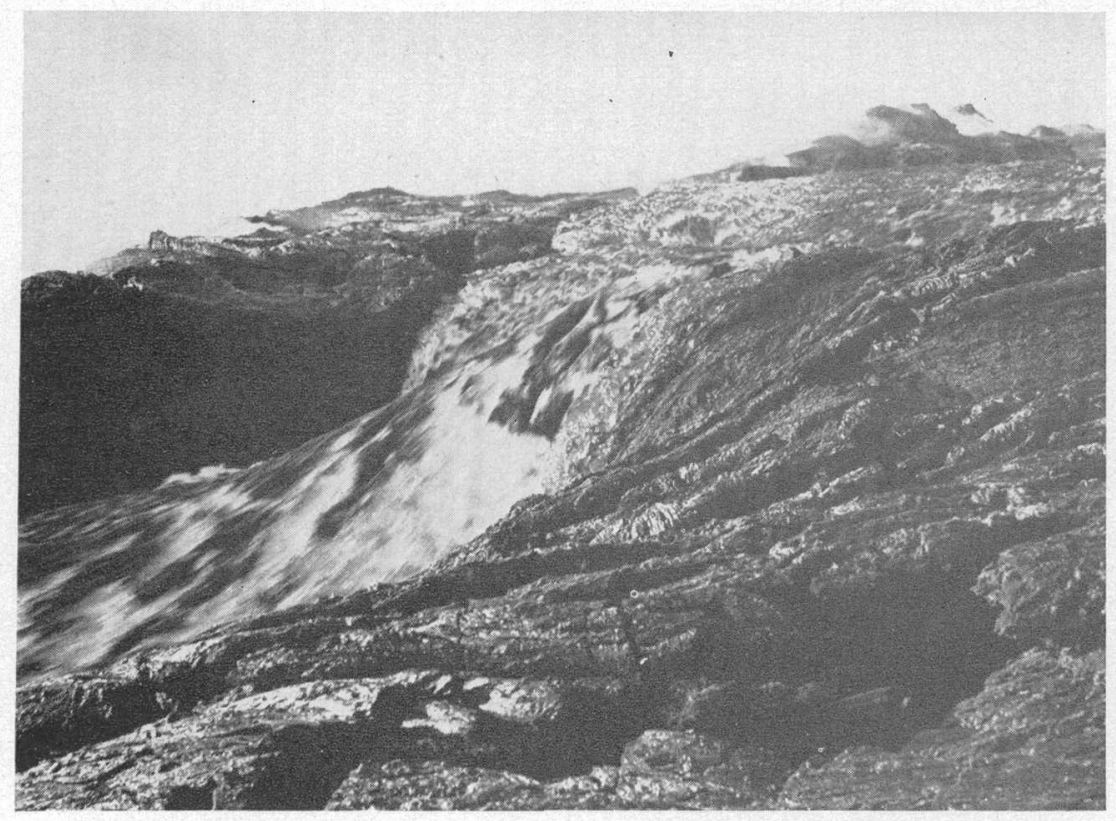

FIGURE 13.-Cascade in the lava river near the vents at 8,440 feet altitude, June 7,1950 . The exposure was taken at $1 / 25$ second, and the blurring of the cascade indicates its speed. The fresh pahoehoe in the foreground was formed by occasional overflows of the river.

Below the cascade the lava river flowed directly along the eruptive fissure, burying several lava fountains, which occasionally shot through the river. Near the foot of the cascade, there was a dome-shaped fountain which averaged about 10 feet across at its base and 5 feet high (fig. 14). This fountain resembled the dome of water which forms over the mouth of some artesian wells. Its brightly glowing hemisphere looked like half an orange set on the lava river. Just upstream from the dome fountain, the rush of the liquid lava leaving the cascade gave rise to a hydraulic jump with a standing wave 4 to 8 feet high (fig. 14).

About 500 feet down the rift from the cascade, a small lava fountain was shooting 10 to 25 feet high. It was not a continuous jet but con- 
sisted of repeated spurts of lava, which separated in the air into large blobs. This fountain was typical of many which could be seen on down the rift. At the base of the fountain lava flowed out in pulses every 1 to 2 seconds, giving rise to a heaving motion much like that commonly observed in a pot of boiling, thick porridge. A small lava shield was building up around the vent, but most of the lava was flowing down the slope of the shield to join the main river. The latter closely paralleled the erupting fissure for about a quarter of a mile, then joined a large stream of lava flowing westward.

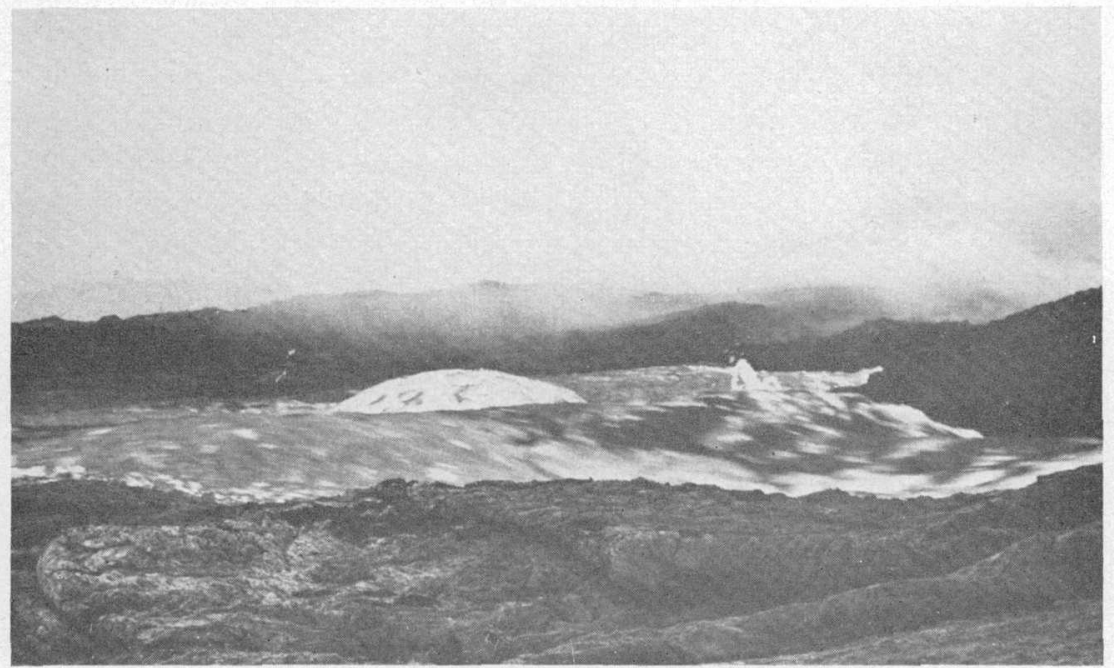

Figne 14.-The lava river at the foot of the cascade shown in figure 13. The stationary wave at the foct of the cascade is visible in the foreground, and behind it the dome fountain, with its top about 4 feet above the surrounding lava. To the right of the dome fountain, near the junction of the branches of the river, a small fountain is exploding through the lava of the river.

Fluctuations in the amount of lava output came at roughly halfhour intervals. Following surges, the level of the lava in the river dropped, exposing along the banks rows of hot flexible lava stalactites, which swayed back and forth in the blasts of gas or as their ends touched the flowing liquid. Many of them eventually were broken off, probably as they became more brittle with cooling, and floated away in the stream.

About 4:30 p. m. on June 7 there commenced a revival of activity along the entire rift. By 7:00 p. m. sporadic lava fountaining could be seen at a distance along the fissure near 10,000 feet altitude, and a little red lava could be seen moving in the heads of the Honokua and Kaohe flows. Along the fissure below 8,900 feet altitude the amount of fountaining and lava outpouring had increased. The surges in the lava river grew in size until during peaks the river channel was filled 
to the brim and locally overflowed sending tongues of pahoehoe rolling toward the observers. The height of the standing wave of the hydraulic jump below the cascade increased to about 12 feet and that of the dome fountain to about 8 feet. The temperature of the lava appeared to increase with the activity, and at 7:20 p. m. pyrometer measurements of both the cascade and the dome fountain gave temperatures of $1050^{\circ} \mathrm{C}$. Some of the lava spilled eastward and formed a stream across the lower end of the former lava pond to the head of the Kahuku flow. Most of it, however, continued to move westward.

As darkness came, many flames were visible over the vents along the rift. Most of the flames were at vents from which lava was no longer issuing, but some were at spattering vents. No flames were observed at vents from which lava was flowing in abundance. Most of the flames were greenish yellow, but some were pale greenish blue. The average length of the flames above the mouths of the conelets was about 5 feet, although some were as much as 20 feet long.

The revival of activity continued until about 2:00 a. m. on June 8 . After that the strength of activity gradually decreased. At 6:00 a. $m$. the rift was still moderately active but much less so than on the previous evening. Roaring gas from a vent at about 8,400 feet altitude was heard occasionally. The cascade at the head of the Kahuku flow was no longer active, and crossing of the flow itself at two places revealed it to be completely dead.

G. D. Robinson and B. J. Loucks reached the Kaapuna flow on the afternoon of June 6 and spent most of the night observing it in the area between the highway and the sea. About half a mile below the highway, the channel divided into two branches, the more southerly of which was the more active. A short distance farther downslope the southerly channel divided so that there were three channels. Surges in activity were observed at approximately half-hour intervals. During lulls in the activity, the lava movement was largely restricted to the central channel, but during the larger surges all three channels became very active. "Will-o-the-wisps" were again observed over the flow. On June 7 the Kaapuna flow was still very active. At the highway the principal movement was in a lava river, which was flowing in a channel about 15 feet deep near the northern edge of the flow. William Stearns reported that a new spur, about 5 or 6 miles long on the southern side of the flow, was advancing slowly.

On June 8 a small overflow occurred on the southern side of the Kaapuna flow about a quarter of a mile above the highway, but the tongue advanced only a few hundred yards before rejoining the main flow. On June 9 the flow appeared to have become distinctly more sluggish. The flow was again visited on June 10 by Robinson and Wentworth, in company with H. R. Joesting and J. H. Swartz. 
Conditions were much the same as they had been when last seen by Robinson on the morning of the 8th. However, since June 8 lava had been newly added to the surface of much of the flow in the vicinity of the road by repeated overflows of the channel. Several surges of activity were observed during the evening, the intervals between surges ranging from 13 to 45 minutes. Pyrometer measurements by Robinson of large glowing blocks in the river and of the surface of the river itself revealed temperatures ranging from $820^{\circ}$ to $920^{\circ} \mathrm{C}$. Cherry-red lava exposed in a cave in the older stationary a margin of the flow gave a temperature reading of $675^{\circ} \mathrm{C}$.

On June 9 a moderate amount of lava was still being liberated, and the eruptive fissure was fuming vigorously (fig. 15).

On June 11 Macdonald and D. H. Hubbard examined the flow where it entered the sea. No movement could be detected in the major part of the flow on the coastal flat, and the volume of steam being formed at the ocean was small. Lava was still pouring over the escarpment a quarter of a mile inland, but it was dull red and appeared more viscous than during earlier observation. 'The speed of the lava on the steep cascade was only about half a mile an hour. Two strong surges of lava at the cascade were observed, one at $2: 30$ and the other at 4:30 p. m. At the foot of the cascade, the lava turned southward and spread out to form a big aa flow, which advanced seaward along the southern edge of the older flow at a rate of approximately 1,000 feet an hour. The front of this flow was the largest the writers have observed in Hawaii. It was about 1,000 feet wide, at least 50 feet high and very active (fig. 16). One after another blocks up to 10 feet in diameter became detached from the top of the flow front and rolled to its base. The blocks were accompanied and followed by trains of fine incandescent debris, and patches of incandescent lava were revealed as the blocks broke away from the front. Clouds of palebrown dust arose from the pulverization of the fragments rolling down the flow front. A hundred yards from the active front the radiant heat was so great that the observer's' faces were scorched, and cameras became so hot they were difficult to hold.

Between 3:00 and 4:00 a. m. on the morning of June 12 there was widespread overflowing of the channel of the Kaapuna flow at the level of the highway. Later in the morning and during the afternoon the glow in the flow was dull, and lava movement was small. Shortly after 9:00 p. m. a bright glow was seen inland from the road, and by 10:15 a new surge of lava was causing flooding on the northern side of the flow. This appears to have been the last big surge. Movement in the flow at the highway stopped on June 13, although on June 14 cowboys of the C. Q. Yee Hop Ranch reported lava still moving in the flow 6 miles above the highway. At about noon on June 15 the 


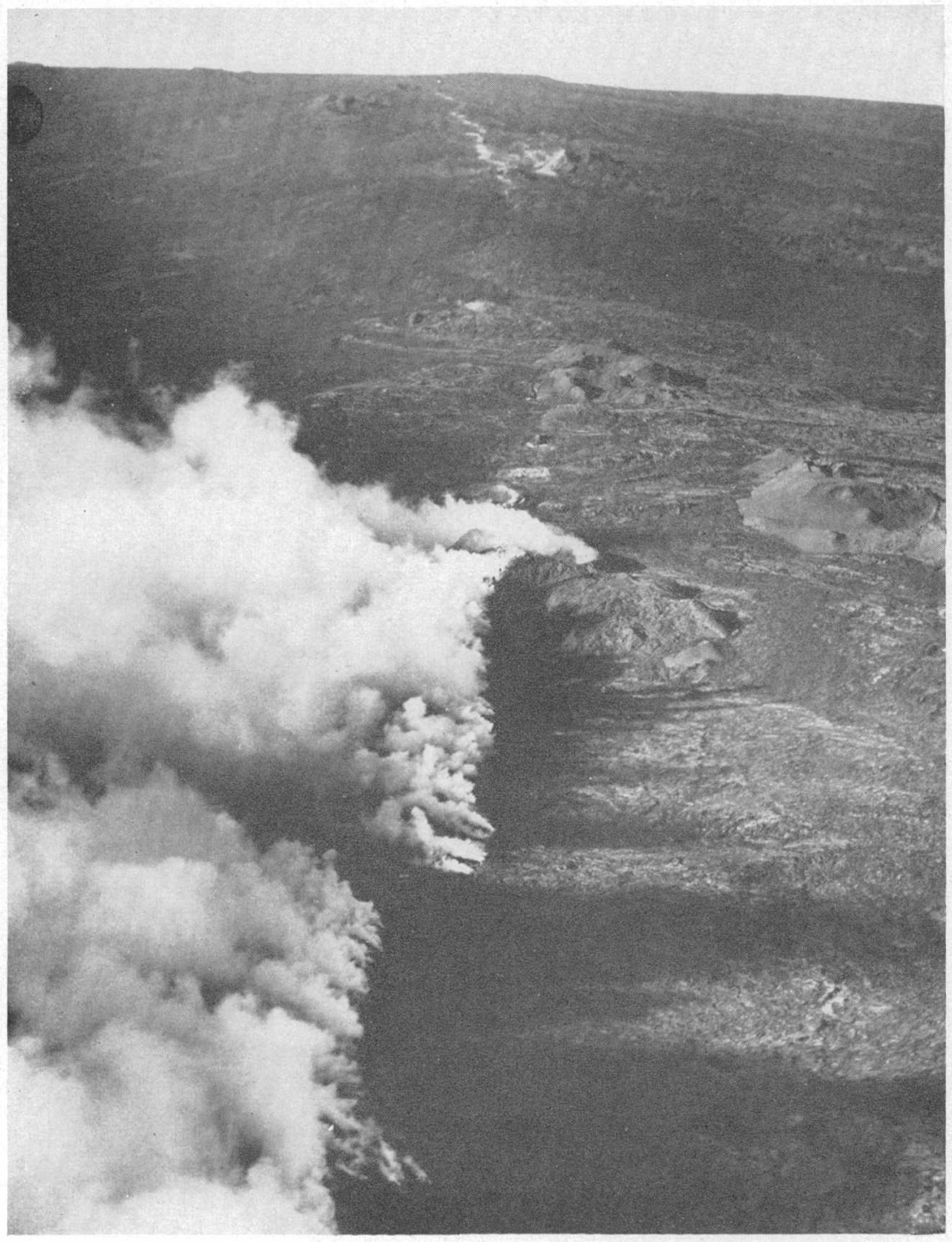

Figure 15.-Heavy fume clouds rising from two segments of the rift between 9,000 and 10,000 feet altitude, June 9, 1950. The heads of the Punaluu and Honokua flows are visible in the middle distance, and behind them fainter fumes rise in the vicinity of Sulphur Cone. (Facing north.) Photo by Werner Stoy, Camera Hawaii.

pilot of a Navy plane reported lava bubbling from the lower 200 yards of the source fissure and about 3 miles of fissure liberating fume. From that time on glow at the source area was observed nearly every night until June 22. On the afternoon of June 22, John Peoples, of the U. S. Coast Guard, flew over the source area and reported hot bubbling lava and a large amount of fume along the rift. 


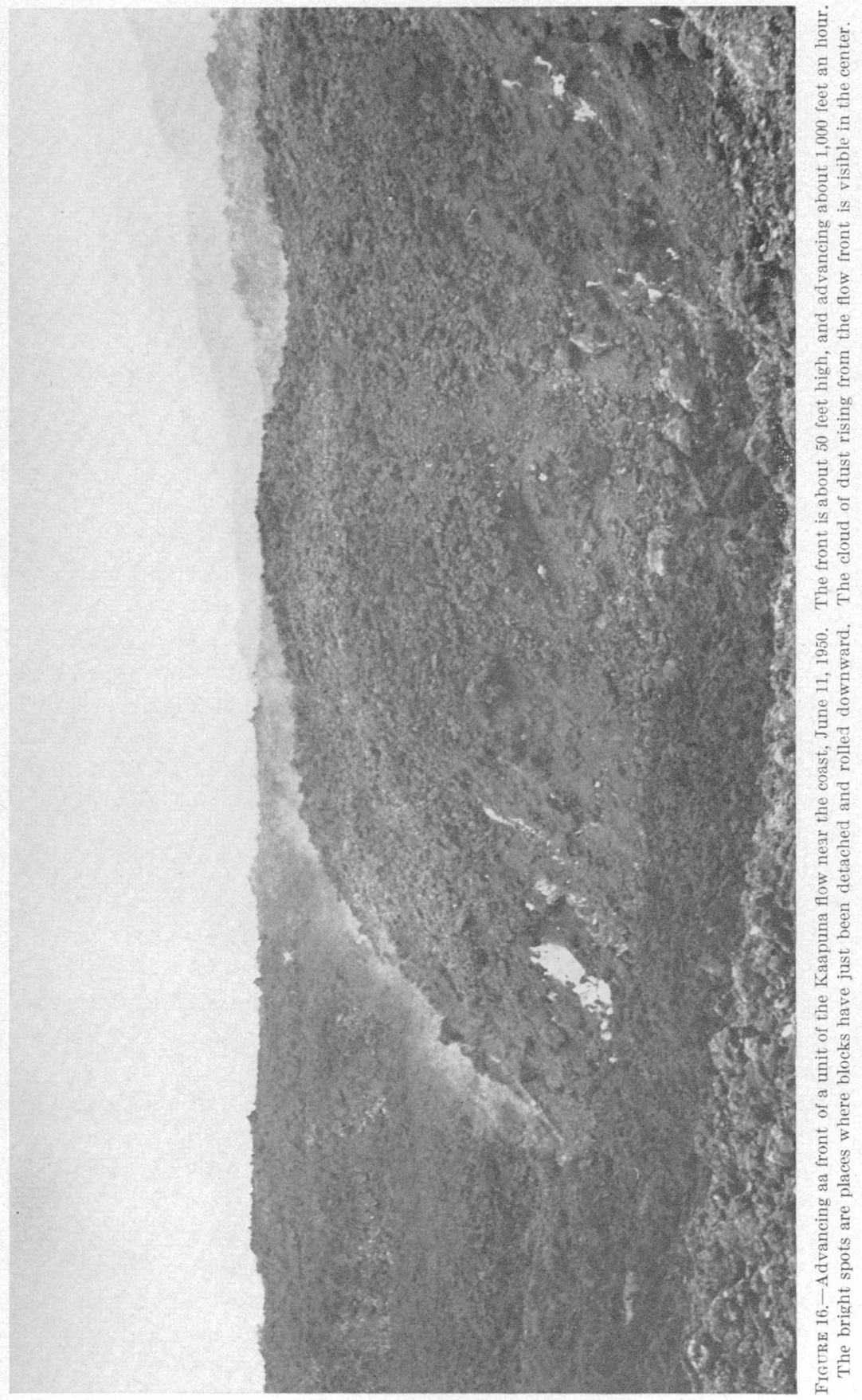


The last well authenticated observation of glow at the source was by Finch, at 1:00 a. m. on June 23, and the eruption is believed to have come to an end on that date. Aerial observations on later days revealed much fume along the fissures, but no signs of moving lava. Fume liberation continued to be abundant through the remainder of June.

\section{LAVA FLOWS}

Composition.-The lava of the 1950 eruption of Mauna Loa ranges from basalt to olivine basalt. The first lava erupted along the upper part of the rift contains very few olivine phenocrysts, and no dunite inclusions were observed in it. In contrast, the lavas erupted later from the portion of the rift below 11,000 feet altitude contain many phenocrysts of olivine, which reach a maximum length of 5 millimeters. Angular inclusions of dunite, as much as 3 centimeters across, are fairly common in the lavas from the lower vents. Some of the dunite inclusions grade toward wehrlite, containing scattered grains of augite. C. S. Ross, of the Geological Survey, has identified bronzite, chrome diopside, and chrome spinel, in addition to the preponderant olivine, in a dunite inclusion from the Kaapuna flow. A few inclusions of fine grained olivine gabbro also are present. All the gabbro inclusions observed contain both olivine and augite, in addition to feldspar; but in some the augite is present only in a very small quantity, and the rock could be classed as a troctolite.

It is probable that the marked difference in abundance of olivine phenocrysts in the early and late lavas is the result of the sinking of the olivine crystals in the magma column before the eruption. 'The first lavas liberated at the upper vents were derived from the upper part of the magma column, which had been impoverished in olivine. Later the lava was derived from a lower level in the magma column, in which the abundance of olivine phenocrysts had been increased by the sinking of crystals from higher levels. A similar and even more marked difference has been found between the early and late lavas of the 1840 eruption of Kilauea (Macdonald, 1944).

Area and volume.-Plate 1 shows the distribution of the lava flows. All of the flows except the upper flow (no. 2) and the Kahuku flow (no. 7) have been plotted from vertical air photographs taken for the Volcano Observatory by the R. M. Towill engineering firm in Honolulu. Flow 2 has been plotted partly from ground observations and partly from aerial photographs taken by E. K. Field and Elroy Bohlin of Hawaii National Park. Flow 7 has been mapped on the ground.

The following table shows the approximate area, volume above sea level, and average thickness of each of the major lava flows of the 1950 eruption. The areas were scaled from the map of the flows. The average thickness of several separate segments of each flow was es- 
timated from ground observations at several points along the flows and from the appearance in the aerial photographs; the average thickness of the whole flow was then calculated from these values. The volumes were calculated by using the scaled areas and the estimates for average thickness of successive portions of the flows. Any error in thickness and volume is probably on the conservative side. The total area of the flows above sea level is 34.9 square miles, and the volume is about 500 million cubic yards. It is estimated that more than 100 million cubic yards of lava flowed out under the ocean and is now lost to view. The total volume of lava erupted, therefore, was very probably more than 600 million cubic yards. 'This is of the same magnitude as the estimated volume (600 million cubic yards) of the largest previous historic eruption, the 1859 lava flow of Mauna Loa (Stearns and Macdonald, 1946, p. 79). Approximate calculations indicate that between a third and a half of the total volume of lava was pured out during the first 36 hours of the 1950 eruption.

Area, thickness, and volume of 1950 lava flows above sea level

\begin{tabular}{|c|c|c|c|c|}
\hline Name of flow & $\begin{array}{l}\text { Number } \\
\text { on mapp } \\
\text { (pl. 1) }\end{array}$ & $\begin{array}{l}\text { Area } \\
\text { (square } \\
\text { miles) }\end{array}$ & $\begin{array}{l}\text { A verage } \\
\text { thicknoss } \\
\text { (feet) }\end{array}$ & $\begin{array}{c}\text { Volume (cubic } \\
\text { yards) }\end{array}$ \\
\hline Upper rift & 1. & 3. 74 . & 4. 5 & $17,000,000$ \\
\hline Upper west flank & 2 & 1. 55 & 7.6 & $15,000,000$ \\
\hline Honokua & 3 & 6. 73 & 8. 3 & $59,000,000$ \\
\hline Kaohe.... & 4. & 5. 74 & 9.3 & $55,000,000$ \\
\hline Punaluu & 5 & 7. 25 & 13.5 & $101,000,000$ \\
\hline Kaapuna & 6 & 8. 47 & 27. 6 & $241,000,000$ \\
\hline Kahuku $\ldots$ & 7 & 1. 44 & 12. 0 & $18,000,000$ \\
\hline Total & & 34.9 & & $506,000,000$ \\
\hline
\end{tabular}

The Kaapuna flow plunged into the ocean from a sea cliff 50 to 75 feet high. The blue of the sea close to the foot of the cliff indicates deep water, and a mile off shore the water is about 2,000 feet deep. Even under these conditions an appreciable advance of the shoreline into the ocean took place. Comparison of photographs taken from the air before and after the eruption indicates an extension of the shoreline averaging about 500 feet. Little change in the position of the shoreline is apparent, however, at the short-lived Honokua and Kaohe flows.

\section{TEMPERATURE MEASUREMENTS}

Approximately 75 readings were made with an optical pyrometer during the eruption. 'The instrument used is a disappearing-filament 
pyrometer with a calibrated circular glass wedge and a red filter of wave length $0.65 \mu$.

About one-third of the readings were made during daylight hours and are of little value. Comparison of readings made during daylight with those made at night indicates that the extraneous illumination during daytime results in readings which are consistently too high. Most daylight readings appear to be from $50^{\circ}$ to $100^{\circ} \mathrm{C}$. higher than readings on the same object at night. The values cannot, however, be successfully corrected, because the amount of extraneous light was variable and undetermined. Therefore, only the night readings have been used, because these values were consistent. Repeated readings on the same nearby object at intervals of a few seconds showed variations of only a few degrees. On the other hand, readings of the surface of the lava river showed a range of approximately $100^{\circ}$, owing at least in part to variations in the proportion covered by crust and the thickness of the crust.

Lava is not an ideal "black body." Its coefficient of absorption of light is less than unity; that is to say, it does not absorb all light incident upon it but reflects part of it. Because the intensity of radiation is a direct function of the absolute temperature only when the coefficient of absorption is unity, the measurements on the incandescent lava do not represent the exact temperature of the lava. A small correction is necessary. The amount of correction has not been determined for Hawaiian lavas, but for leucite basanite of Volcan Nyamlagira in the Belgian Congo, Verhoogen (1948, p. 131) found the correction to be about $20^{\circ}$ at $1,000^{\circ} \mathrm{C}$. It is probable, therefore, that the observed temperatures given in the following table should be increased by about $20^{\circ} \mathrm{C}$.

It is noteworthy that the temperatures of the dome fountain and the river at the vents $\left(1030^{\circ}-1080^{\circ} \mathrm{C}\right.$.) are of the same order of magnitude as those obtained by Verhoogen (1948, p. 133-136) at Volcan Nyamlagira. In comparison the temperature at the surface of the Kilauea lava lake in 1916 was about $1,000^{\circ}$, that at a depth of 1 meter was about $860^{\circ}$, and that at a depth of 13 meters was about $1,170^{\circ}$. The latter temperature was believed to be higher than that of the magma rising through the conduits (Jaggar, 1917). The high temperature of $1,100^{\circ}$ measured in the throat of the inactive spatter cone on June 7, 1950, probably was partly the result of gas heating.

There probably was very little lowering of apparent temperature by crust on the very turbulent lava in the river at the vents, and the actual temperature of emission of the lava may be taken as close to $1,070^{\circ}$. On the other hand, most of the readings on the lava river at the highway probably were to some degree affected by the presence of crust on the river. The actual internal temperature of the river' 
'T'emperutwe measurements aluing the 1950 eruption

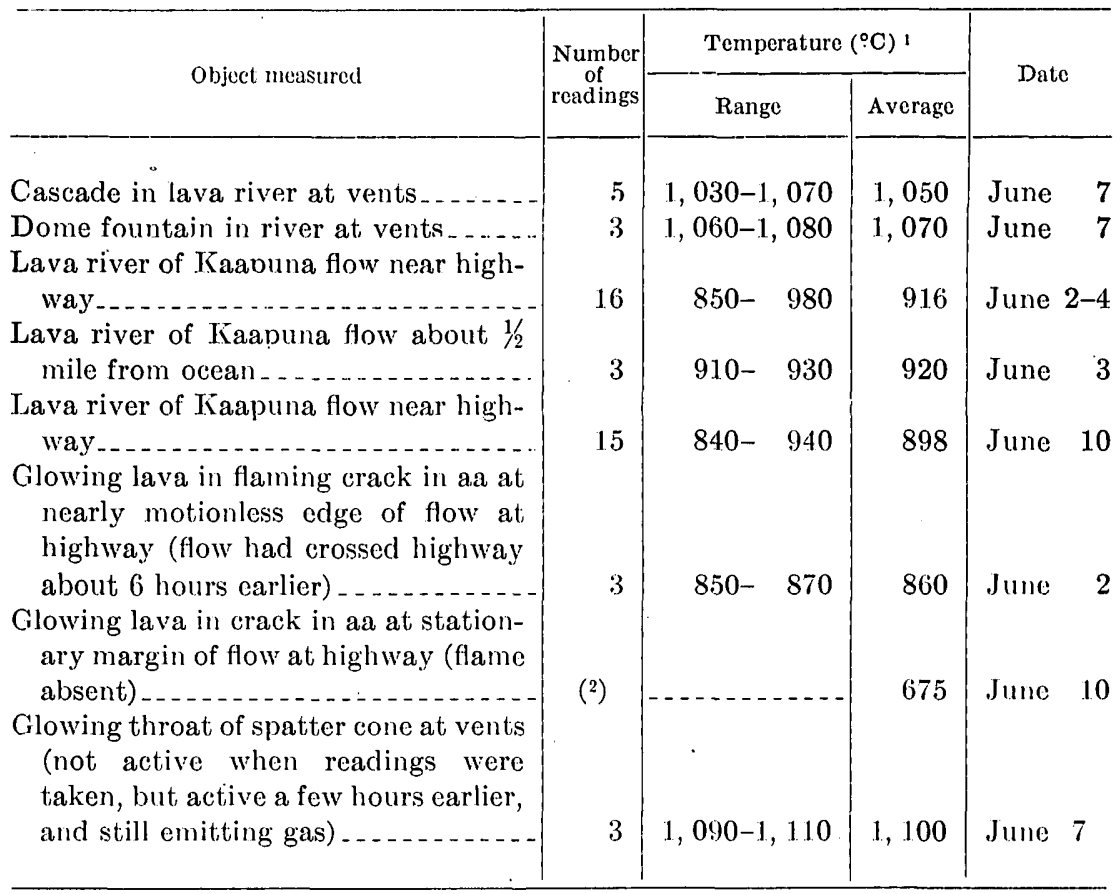

${ }^{1}$ Uncorrected night readings with an optical pyrometer. The true temperatures probably aro about $20^{\circ}$ higher.

2 Several.

at the highway was probably near the upper end of the range of observed temperatures, about $950^{\circ}$. Thus, the lava of the Kaapuna How cooled about $100^{\circ}$ in traversing the 10 miles from the vents to the highway. At $950^{\circ}$ it was still fluid and free-flowing; at $675^{\circ}$ it. had become immobile. The temperatures of 850 to $870^{\circ}$ measured in cracks in the stagnant aa on June 2 may have been appreciably higher than the internal temperatures, because of surficial heating by burning gases. During the 1949 eruption of Mauna Loa, lava with a temperature of about $760^{\circ}$ was found to be still capable of a little movement (Macdonald and Finch, 1949, p. 5).

On November 18, 1950, temperature measurements were made at several hot cracks in the Kaapuna flow near the highway. Measurements ranged from $165^{\circ}$ to approximately $400^{\circ} \mathrm{C}$. The highest temperature was obtained at a crack near the center of the flow about 200 feet up slope from the highway at a depth of 18 inches beneath the surface. Crookedness of the crack prevented measurements being made at greater depth. The crack was an active secondary fumarole at which sulfur and white salts, probably largely sodium sulfate, were being deposited. Subsequent measurements made through 1951 showed no apparent change of temperature at the hottest crack. 
On March 20, 1952, the Highway Department of the Territory of Hawaii installed a recording thermometer on the flow at a hot crack approximately 150 feet south of the hottest crack measured by Macdonald during 1950 and 1951. According to K. B. Hirashima (personal communication), a temporary installation with the thermal element at a depth of 18 inches yielded a temperature reading of $460^{\circ} \mathrm{C}$, and the permanent installation at a depth of 3 feet yielded a reading of $515^{\circ}$. This local high temperature is caused by gases rising from the lower part of the flow, which is approximately 50 feet thick at that point.

\section{RADIATION STUDIES}

Two series of counts with a Geiger-Mueller counter were made at 11 stations along the highway at and near the Kaapuna flow on June 2 and 5 . The number of clicks per minute varied considerably, but the averages close to the flow and on the flow are a little less than that at a distance from the flow. The averages are as follows:

500 to 1,000 feet from flow
10 to 300 feet from flow per minute
On flow 75 to 250 feet from edge

It is possible that the higher temperature on and near the flow affected the sensitivity of the instrument, reducing the count. However, at no time was the temperature of the wand holding the tube high enough to be unbearable, or even particularly uncomfortable, to the unprotected hand of the operator. The evidence appears to indicate that there was no marked increase in radiation as the flow was approached, and therefore that the lava was not appreciably radioactive at the level of the highway. No counter readings were made at the vents.

Samples of lava collected where the flow crossed the road showed no radioactivity when tested by Dr. Harvey E. White of the University of California.

\section{TILTING OF THE GROUND}

Indications of a pressure build-up under both Kilauea and Mauna Loa volcanoes in February, March, April, and May were given by the tilt curves obtained at the Whitney Laboratory of Seismology on the northeast rim of Kilauea caldera. Normally there is a seasonal southwestward tilting during the first five months of the year (Powers, 1947, p. 2). In 1950, however, seasonal tilting was exceeded by volcanic tilting in the opposite direction so that southward tilting ceased on February 9 and westward tilting on March 19. 
A rapid northward tilting started on March 6 and continued until the end of June, except for a southward tilting of 2.2 seconds of arc from May 29 to June 5. Over half of this southward tilt, or $1.2 \mathrm{sec}-$ onds, accompanied a strong earthquake on May 29. The northward tilt from March 6 until May 29 amounted to 11.5 seconds of arc. The 77 earthquakes recorded in April, a majority of which originated at Kilauea, together with the strong northward tilt, indicated a distinct uneasiness of Kilauea volcano.

A distinct eastward tilting, which followed the cessation of seasonal westward tilt on March 19, continued through May 28. The 102 earthquakes recorded during May, a majority of which originated under Mauna Loa, together with the eastward tilting, indicated that Mauna Loa had become more uneasy than Kilauea. There was a sharp westward tilt on May 29 and 30 following the strong quake on May 29. Despite some fluctuations there was an accumulation of 6.0 seconds of arc of eastward tilt from May 31 to June 14 . It is interesting to note that strong eastward tilting accompanied the outbreak of Mauna Loa and continued until there was a noticeable decrease in lava output. Evidence is accumulating that there is a correlation between eastward tilting and Mauna Loa eruptions. In 1950 eastward tilting commenced 2 months and 12 days prior to the outbreak of Mauna Loa. Distinct eastward tilting began 2 months and 8 days before the beginning of the 1949 eruption.

\section{HARMONIC TREMOR}

For more than an hour after the eruption began, very conspicuous harmonic tremor (Finch, 1944) was recorded on the seismographs at Kilauea, on the eastern slope of Mauna Loa, and at Kealakekua in Kona. The maximum double amplitude recorded by the BoschOmori seismograph at the Whitney station was 5 millimeters, and the average period was 0.5 second. The amplitude of this early tremor was several times greater than that recorded during the summit eruptions of 1940 and 1949, despite the fact that the early vents of the 1950 eruption were at a distance of 24 miles, about two miles farther from the station than the vents of the earlier eruptions.

The recording of harmonic tremor commonly dies out after the first few hours of the eruption. However, in 1950, although it decreased greatly in amplitude after the first 1.5 hours, it continued intermittently until June 13. Although after the first few hours of the eruption the active vents were about 30 miles from the Whitney station, harmonic tremor was recorded clearly on the Bosch-Omori seismograph. The double amplitude of the tremor reached a maximum of 
0.7 millimeter, and the period ranged from about 0.4 to 1.5 seconds. The amplitude was larger than that of the tremor recorded during the 1940 and 1949 eruptions, although the vents of the earlier eruptions were at a distance of only 22 miles. Figure 17 shows harmonic tremor characteristic of the 1950 eruption.

The large amplitude of the harmonic tremor at the beginning of the eruption and the fact that tremors continued to be recorded after the distance to the source increased from 24 to 30 miles, indicated that the rate of output of lava was greater than usual.

On June 3 it was noticed that the harmonic tremor was not continuous, indicating fluctuations in the volume of lava being emitted. Direct observations both at the source and where the lava crossed the road showed fluctuations in volume.

Whether the harmonic tremor is produced by movements of lava in the primary conduits under the summit caldera of Mauna Loa, or in the fissures of the rift zones which serve as channels for the rise of lava to the surface, is not known, though available evidence favors the latter. In most eruptions harmonic tremor is recorded for only a few hours. In the 1942 flank eruption, harmonic tremor was recorded for a few hours during the preliminary activity at the summit, 22 miles from the Whitney station, and then for seven days after the lava broke out along the northeast rift at a distance of only 14 miles from the station. 'The fact that the tremor ceased a little before the end of the summit activity and resumed to continue for seven days after the lava broke out 10 miles down the northeast rift zone suggests strongly that the tremor originates in the eruption fissures.

On June 2 another type of harmonic tremor, apparently not previously recorded at the Hawaiian Volcano Observatory, was noticed (fig. 18). The most frequent period of this type of tremor is roughly two seconds. Fourteen periods of this type of tremor were recorded on June 3 and thirteen on June 4. Smaller numbers were recorded on other days, with the last on June 12.

\section{EARTHQUAKES}

Earthquakes and tilting of the ground surface during March and April caused speculation as to the possibility of an eruption at Kilauea. In May, however, quakes of Kilauea origin became less numerous, and those originating at Mauna Loa predominated. Many of the Mauna Loa quakes originated under the upper end of the southwest rift zone. 


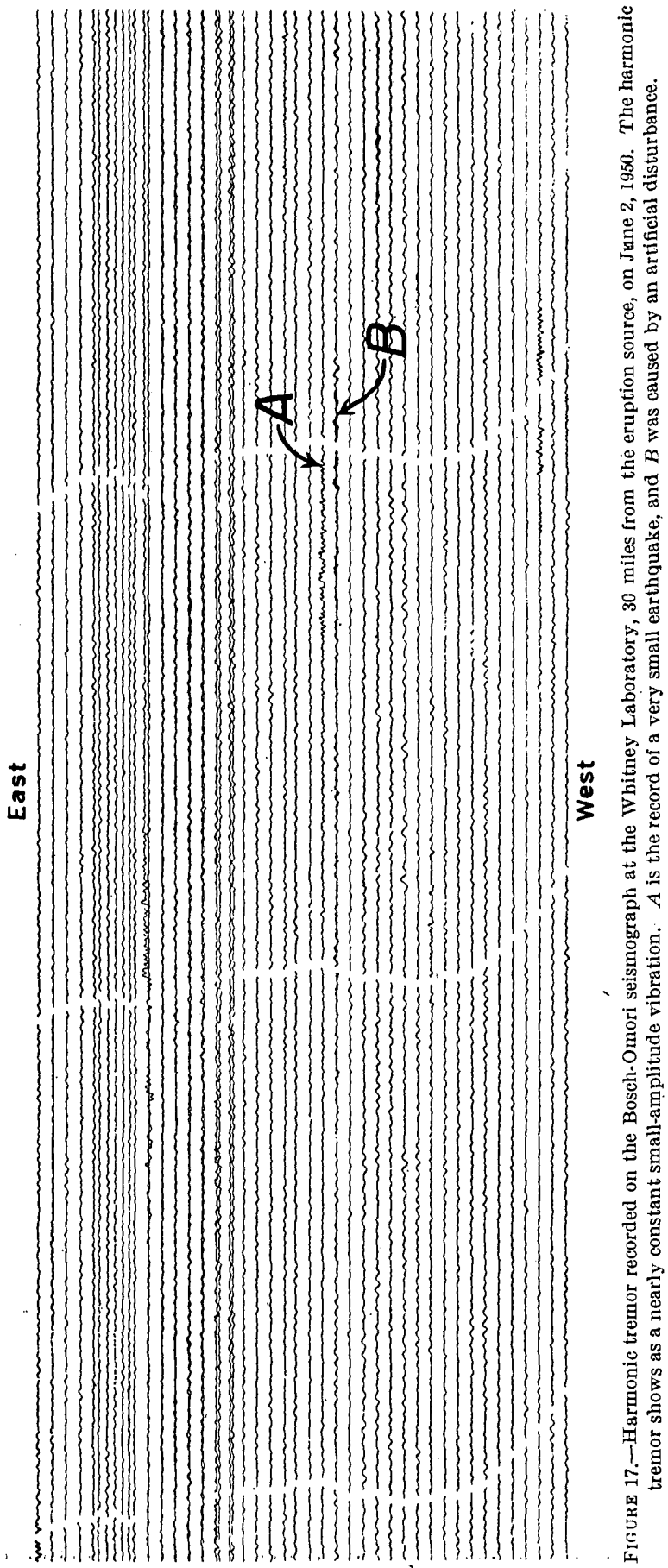




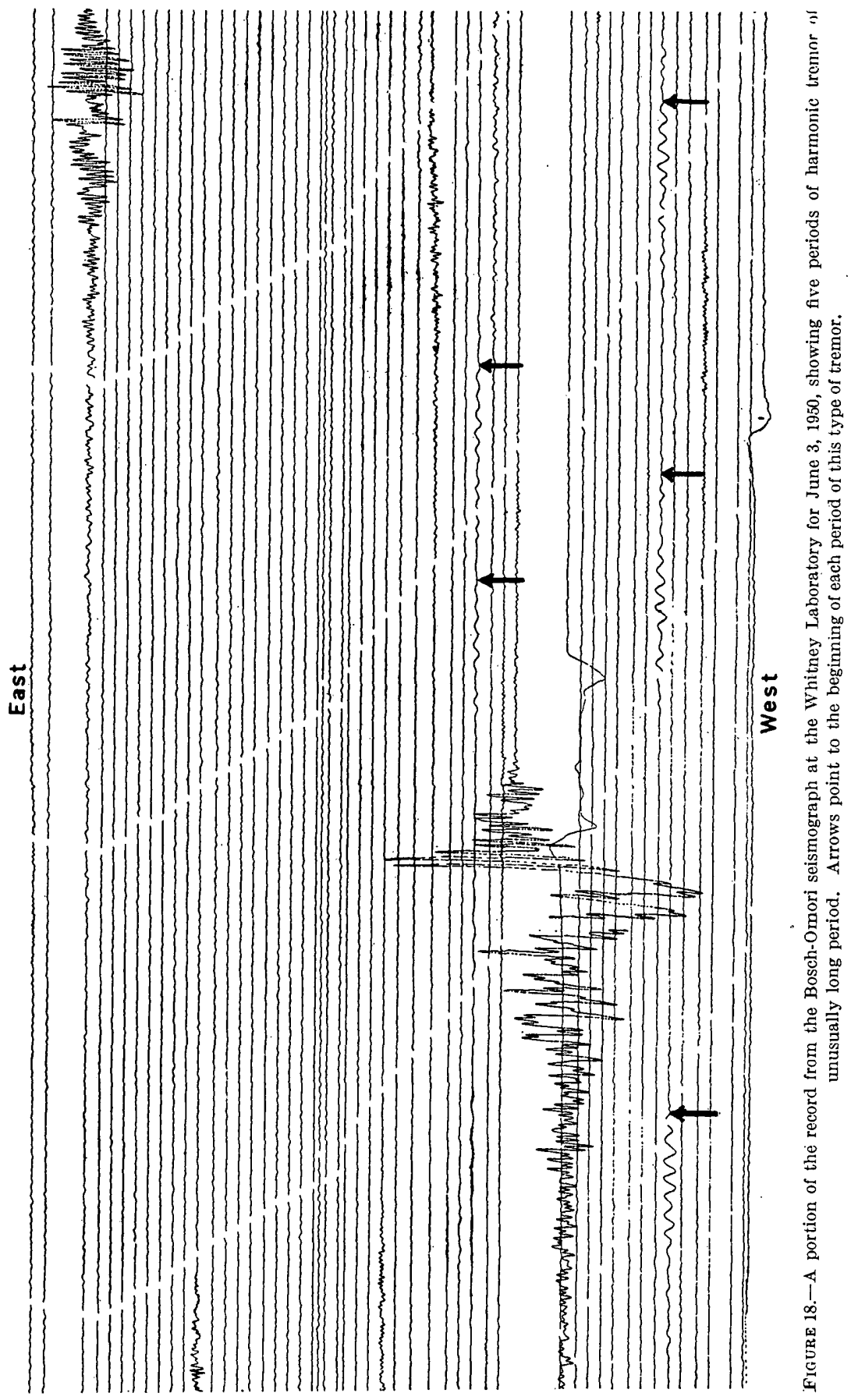


The following table shows the number of earthquakes per week recorded at the Whitney station during May and June. Normally, when both Mauna Loa and Kilauea are quiet, only 5 or 6 earthquakes per week are recorded. Of the 58 earthquakes during the week of May 28, 14 occurred after the beginning of the eruption.

Local earthquakes recorded at Whitney station during the 1950 eruption of Mauna Loa

\begin{tabular}{|c|c|c|c|}
\hline Week beginning & $\begin{array}{l}\text { Number } \\
\text { of quakes }\end{array}$ & Week beginning & $\begin{array}{l}\text { Number } \\
\text { of quakes }\end{array}$ \\
\hline April 30... & 30 & June $4 \ldots \ldots$ & 158 \\
\hline May $7 \ldots \ldots$ & 21 & June $11 \ldots$ & 60 \\
\hline May 14 & 18 & June 18 & 11 \\
\hline May 21 & 9 & June 25 & 7 \\
\hline May $28 \ldots$ & 58 & & \\
\hline
\end{tabular}

A larger number of earthquakes during the early part of a flank eruption than during a summit eruption is to be expected because of the greater length of fissuring. In 1950 there was a progressive fissuring of the southwest rift for a distance of 13 miles.

\section{LITTORAL EXPLOSIONS}

The absence of large littoral explosions or the formation of much ash where the lava entered the ocean was a striking feature of the 1950 eruption. Many aa flows entering the sea cause violent steam explosions, which throw into the air large amounts of ash and build littoral cones of ash and cinder (Macdonald, 1944). This happened in $1840,1868,1919$, and 1926 (Jaggar, 1919, 1926). Many pahoehoe flows enter the water quietly, with only moderate evolution of steam, because the quickly-formed pahoehoe skin forms an insulation that separates the very hot lava inside from the water. Aa flows, on the other hand, typically have a much broken and discontinuous surficial layer, which permits the water easy access to the hot interior, with resultant strong explosions.

A minor amount of littoral explosion did occur during the 1950 eruption. On June 3 D. C. Cox, going down the southern edge of the Kaapuna flow with D. A. Davis and C. K. Wentworth, noticed an increase in the amount of falling ash as they approached the coast and came under the steam cloud. Also some of the moving pictures taken from the sea show small puffs of dark, ash-laden cloud mixed with the white steam. Small deposits of typical black littoral ash lie on the Kaapuna flow at the coast. However, littoral explosion and ashmaking were very minor, certainly not nearly comparable with that in 1919 and 1926. Probably this was because the main lava rivers entering the sea were hotter and had a more unbroken surface than those of the 1919 and 1926 flows, thus preventing rapid and easy entrance of the water to the hot interior. Once the flow into the ocean 
was well established a continuous crust may have formed over the lava river, acting as an insulator in much the same way as does the pahoehoe skin. Figure 19 shows a lava river of this sort entering the sea and producing only a little steam. Whenever a large block of hot lava carried along by the lava river was dumped into the sea, it did produce a large burst of steam. The occasional small littoral explosions probably occurred when some special circumstance caused the temporary disruption of the crust, admitting water to the hot interior of the flow.

Explosions similar to littoral explosions apparently occurred at, some places on land, probably where the lava encountered swampy or very wet soil conditions. A.bout 2 miles east of the highway at the southern side of the Kaohe flow, an area of several acres is covered with a thin deposit of sandy and silty ash. This material has been examined microscopically and found to consist largely of moderately vesicular to dense, angular fragments of basaltic glass similar to that typical of littoral cones but different from the highly vesicular; scoriaceous, or pumiceous material characteristic of the deposit, around true vents (Macdonald, 1949, p. 72).

\section{THE DECEMBER 1950 SUBSIDENCE AT KILAUEA}

At noon on December 8, 1950, after several weeks of generally normal seismic conditions, the frequency of earthquakes recorded by the seismographs suddenly increased. Simultaneously a rapid southwesterly tilt started at the Whitney station on the northeast rim of Kilauea and an easterly tilt at the Uwekahuna station on the west rim. This strong tilting indicated a subsidence of the crateral region of Kilauea volcano.

The origins of the early earthquakes were in the vicinity of Kokoolau crater, (pl. 2) four miles from the Whitney station, under the upper end of the system of fissures, which connect the east and southwest rift zones of Kilauea volcano (pl. 2). During the night of December 8 to 9 , some earthquakes continued to originate in the same region as the early shakes, but others originated at greater distances from the station as though there was a progressive cracking to the southwest. By early morning of December 9, many of the quakes were plainly felt at Kapapala (pl. 2). The indicated origin of some of the stronger shakes on this date was a little to the east of the Kamakaia Hills. The strongest quake of the series occurred at $11: 25 \mathrm{p}$. m. on December 10 and was generally felt over the eastern half of the island of Hawaii. Its origin also was a little to the east of the Kamakaia Hills.

The epicenters of the quakes were distributed over a linear extent of 15 miles, from the Chain of Craters Road to the southwest rift about 4 miles southwest of the Kamakaia Hills. The indicated depth of focus of many of the earthquakes was 4 to 5 miles. 


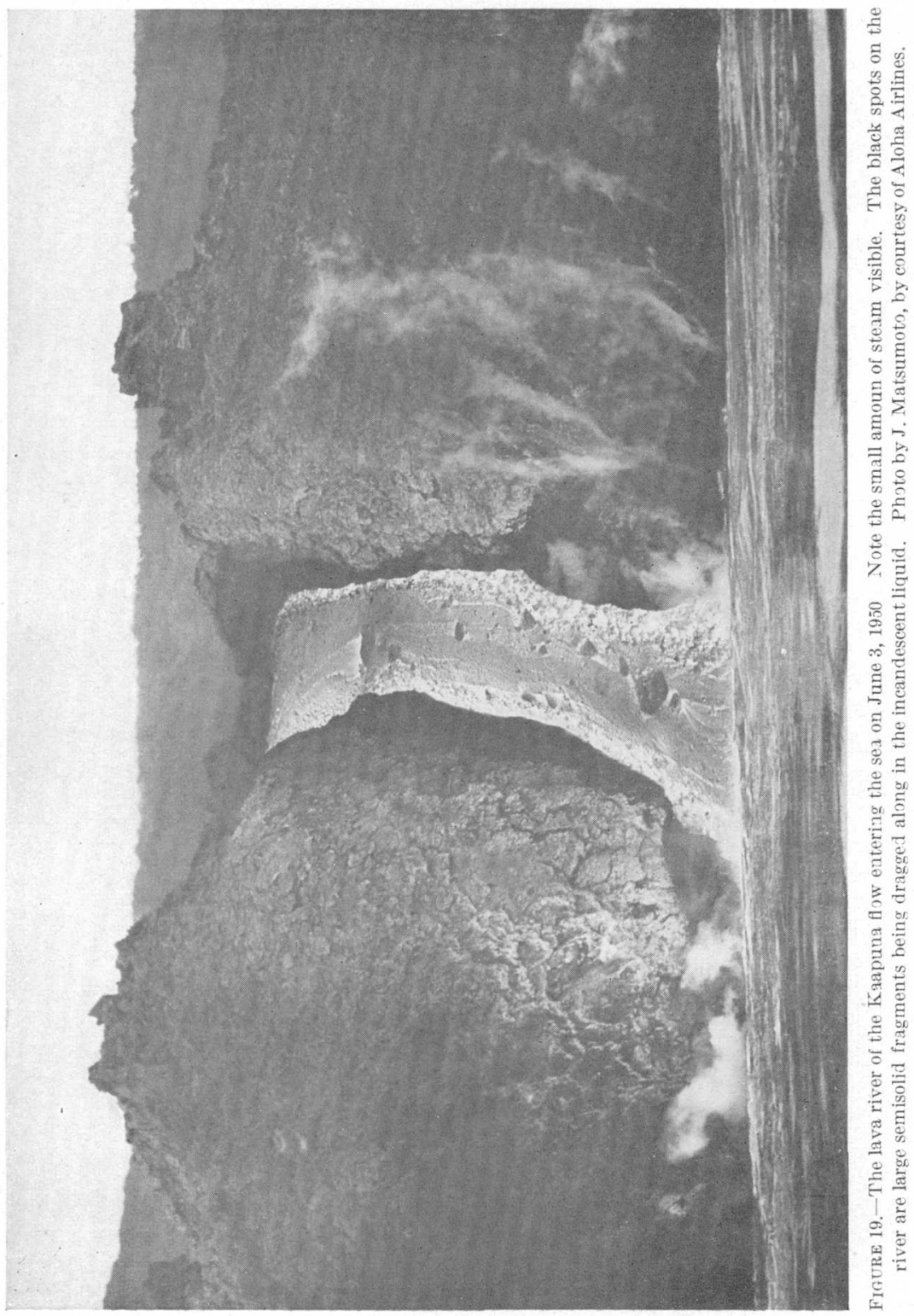


The total number of earthquakes recorded during the period of rapid subsidence, December 8 to 14 , was at least 656 . The maximum number of quakes in any one day was more than 200 on December 10. For several hours each day on December 8,9 , and 10 , quaking was so nearly continuous that it was impossible to separate the records of numerous small quakes. The following table shows the number of earthquakes per day:

Local earthquakes recorded at Whitney station during the December 1950 subsidence at Kilauea

\begin{tabular}{|c|c|c|}
\hline Number of quakes & Number & Number of quakes \\
\hline Dec. 8 & $\ldots$ & 33 \\
\hline Dec. 9 & Dec. 13 & 17 \\
\hline Dec. 10 & Dec. 14 & 12 \\
\hline Dec. 11 & & \\
\hline
\end{tabular}

On December 11 a crack was discovered across the pavement of the Chain of Craters Road near Kokoolau Crater, 0.35 mile northwest of the Hilina Pali road junction (fig. 20). It is believed probably to have been opened by the strong earthquake at 9:25 p. m. on December 10 . The bearing of the crack was N. $29^{\circ} \mathrm{E}$. The ground on the northwestern side of the crack toward Kilauea caldera was slightly depressed wih relation to the southeastern side. There was a vertical displacement of 1.5 centimeters at the northern edge of the pavement but at the southern side, where the crack had opened about 1.3 centimeters there had been no vertical movement. The pavement showed signs of compression and buckling at the northern side and tension at the southern side. The crack also showed clear evidence of horizontal offset, the southeastern side having moved northeastward. The evidence of horizontal displacement consisted of the opening of portions of the irregular crack that trended northward or northwestward and closing, with slight buckling and overthrusting of the pavement on portions striking more easterly than N. $29^{\circ}$ E. The compression at the northern edge of the pavement of a portion of the crack with an eastward strike probably resulted from horizontal displacement essentially parallel to the average trend of the crack. The total movement on the crack, thus, was down and southwestward on the northwestern side, the total displacement being about 2 centimeters.

Measuring points were set on the two sides of the fault near the southern edge of the pavement. Measurement on December 26 showed that the pavement on the southeastern side of the fault had moved northeastward an additional 6 millimeters. The movement may all have taken place during a moderate earthquake at $2: 55 \mathrm{a}$. $\mathrm{m}$. December 26. The measuring points were destroyed by regrading of the road during January 1951, but no further signs of movement along the 


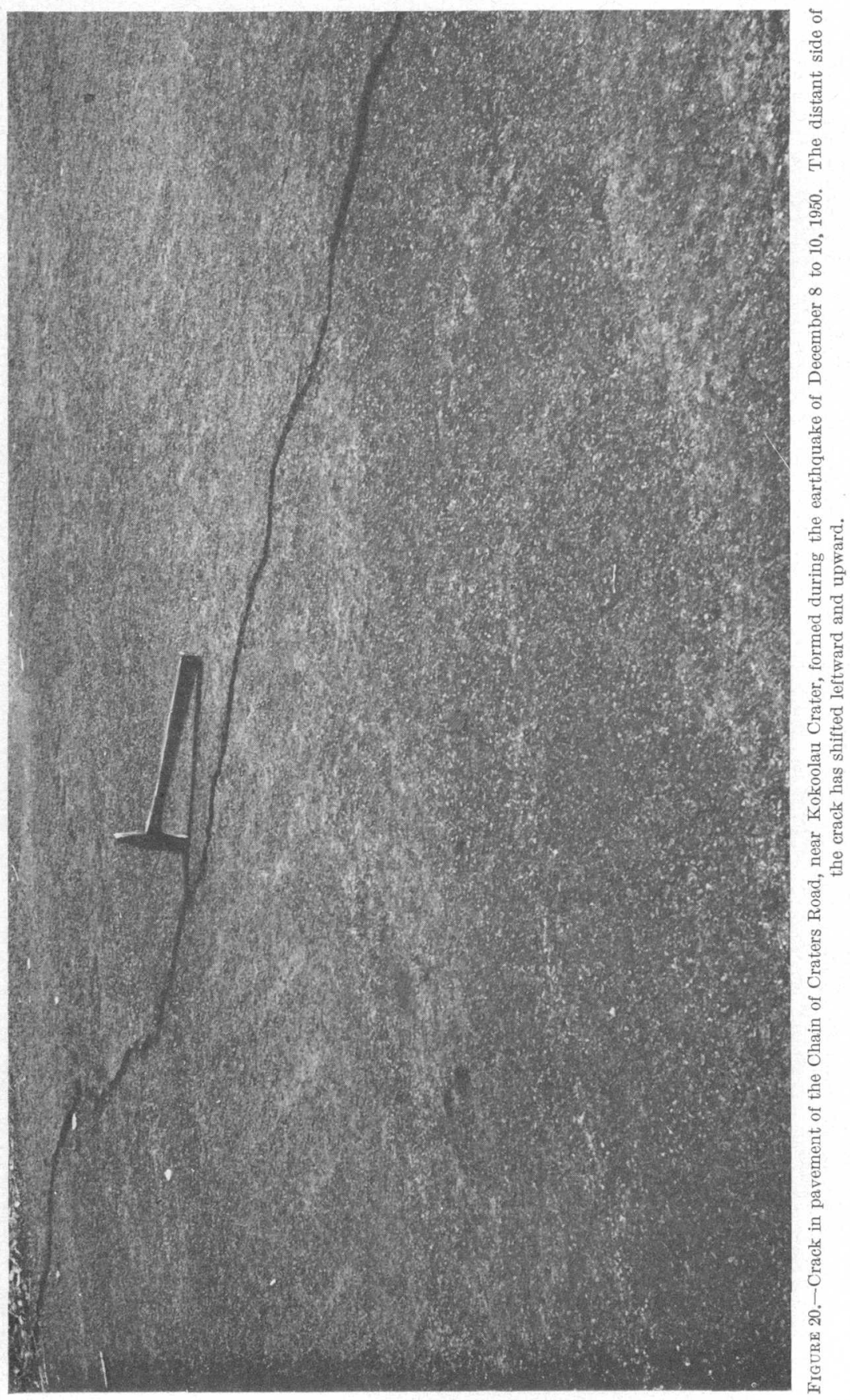


fault have been observed. Another crack extended part way across the pavement 5 feet farther southeast, but there was little evidence of movement along it.

Two small northeast-trending cracks in loose surficial ash were later discovered about two miles southwest of Kokoolau Crater (pl. 2). They may have resulted merely from lurching of the ash.

The fact that the earthquakes accompanied a rapid subsidence of the entire top of Kilauea was shown by tilt records. A seasonal northeastward tilt generally continues until the latter part of December, when a seasonal change to southwestward tilting usually occurs. A rapid southwestward tilt at the Whitney station started on December 8 and continued for four days with a cumulative total of 14.5 seconds of arc. During the same four days the total at the Uwekahuna station (fig. 4) was 22.1 seconds of arc to the east-southeast. In both instances tilting was much more rapid than the normal seasonal tilting. These values place the maximum subsidence a little to the northeast of Halemaumau at about the same position as that of the maximum subsidence of 1920-24 determined by Wilson (1935) on the basis of differential leveling.

The following table shows the amount and direction of tilting during the earthquake swarm. The tilt curves at the Whitney station are shown in figure 4. At all stations except the southeast tilt cellar, the direction of tilting remained the same throughout the period. The change in direction at the southeast tilt cellar probably was caused by an irregular settling of the block on which it is located. Using the values given in the table, and assuming uniform tilting and a hinge line at the Whitney and Uwekahuna vaults, we obtain by calculations an indicated amount of sinking of the ground surface at Halemaumau of 0.8 and 0.6 feet respectively. Actually the hinge line certainly was much farther out, and the tilting was not uniform but increased toward Halemaumau (as shown by the records at the west and southeast tilt cellars). Allowing for these factors, the maximum subsidence in December 1950 certainly exceeded one foot.

Tilt during the earthquake swarm in early December 1950

\begin{tabular}{|c|c|c|c|}
\hline Station (see locations, pl. 2.) & Interval & Direction & $\begin{array}{l}\text { Amount } \\
\text { (seconds } \\
\text { of arc) }\end{array}$ \\
\hline Whitney vault $\ldots \ldots$ & Dec. 8 to $12 \ldots$ & S. $28^{\circ} W_{\ldots} \ldots$ & 14. 5 \\
\hline Uwekahuna vault . . . . . . & Dec. 8 to 12 & S. $55 \frac{1}{2}{ }^{\circ} \mathrm{E}_{\ldots} \ldots$ & 22. 1 \\
\hline West tilt cellar & Nov. 30 to Dec. $13 \ldots$ & S. $861^{1 / 2^{\circ}} \mathrm{E} \ldots$ & 28. 6 \\
\hline \multirow[t]{2}{*}{ Southeast tilt cellar...... } & Nov. 30 to Dec. $10 \ldots$ & N. $82^{\circ} W_{\ldots}$ & 140.3 \\
\hline & Dec. 10 to 13 & S. $75^{\circ} \mathrm{E}$ & 33.8 \\
\hline
\end{tabular}

1 Partly estimated. 
The sinking implied by the 14.5 seconds of arc of south-southwestward tilt is less than the implied tumescence during the five month period of March-July.1950, when there was a tilt of 21 seconds to the north-northeast.

Tilting, earthquakes, and cracks at the surface indicate that a considerable area, probably several miles in diameter around Kilauea caldera, subsided. The location of the earthquakes and the new cracks indicate that a triangular block bounded by the east and southwest rifts and a line from Kokoolau Crater to the southwest rift near the Kamakaia Hills underwent a greater movement than adjacent areas.

Several short spells of harmonic tremor recorded on December 10 and 11 indicate that there was some subsurface movement of magma probably at a depth of four or five miles (the depth of focus of many of the earthquakes). Tilt records indicate that pressure continued to build up under Kilauea for nearly two months after. Mauna Loa ceased to erupt in June 1950. The rapid subsidence in the vicinity of Kilauea caldera in December unquestionably indicates a decrease of pressure beneath the caldera, presumably due to withdrawal of magma. Whether the withdrawal was accomplished by a vertical retreat of the lava column to greater depth or by a more or less horizontal drainage into the rift zones is not known. The migration of earthquake foci southwestward suggests a progressive opening of the southwest rift, which may have been accomplished by lateral drainage of the magma from beneath the caldera. On the other hand, the southwestward progression of earthquakes did not continue appreciably beyond the boundaries of the triangular subsiding block mentioned above. It appears probable that the earthquakes arose largely or entirely from subsidence of the triangular region about the caldera, rather than from tearing open of the rifts, and that the subsidence was caused by an essentially vertical retreat of the magma column.

\section{IITERATURE CITED}

Allen, E. T., 1922, Preliminary tests of the gases at Sulphur Banks, Hawaii: Hawaiian Volc. Obs. Bull., v. 10, p. 89-93.

Brigham, W. T., 1868, Notes on the volcanic phenomena of the Hawaiian Islands, with a description of the modern eruptions: Boston Soc. Nat. Hist. Mem., v. 1, p. 369-431.

Finch, R. H., 1926, Volcanic flames: Volcano Letter, no. 78, p. 1.

$\longrightarrow, 1943$, Lava rivers and their channels: Volcano Ietter, no. 480, p. 1-2.

- 1944, Harmonic tremor: Volcano Letter, no. 483, p. 1-2.

Finch, R. H., and Macdonald, G. A., 1950, The June 1950 eruption of Mauna Loa: Volcano Letter, no. 508, p. 1-11; no. 509, p. 1-6.

- -1951 , Report of the Hawaiian Volcano Observatory for the years 1948 and 1949: U. S. Geol. Survey Bull. 974-D, p. 103-133. 
Jaggar, T. A., 1917, Volcanological investigations at Kilauea: Am. Jour. Sci., 4th ser., v. 44, p. 161-220.

1919, Activity of Mauna Loa: Hawaiian Volcano Observatory Bull., v. 7 , no. 10 , p. 151 .

1926, Journal of Mauna Loa eruption: Hawaiian Volcano Observatory Bull., v. 14, p. 41-42:

Jaggar, T. A., and Finch, R. H., 1929, Tilt measurements for thirteen years at the Hawaiian Volcano Observatory: Seismol. Soc. America Bull., v. 19, p. $38-51$.

Macdonald, G. A., 1944, The 1840 eruption and crystal differentiation in the Kilauea magma column: Am. Jour. Sci., v. 242, p. 177-189.

- 1949, Petrography of the island of Hawaii: U. S. Geol. Survey Prof. Paper 214-D, p. 51-96.

- and Finch, R. H., 1949, The Mauna Loa eruption of January 1949: Volcano Letter, no. 503, p. 1-7.

- and Orr, J. B., 1950, The 1949 summit eruption of Mauna Loa, Hawaii: U. S. Geol. Survey Bull: 974-A, p. 1-31.

Payne, J. H., and Ballard, S. S., 1940, The incidence of hydrogen sulfide at Kilauea solfatara preceding the 1940 Mauna Loa volcanic activity: Science, v. 93 , no. 2384, ,p. $218-219$.

Powers, H. A., 1947, Annual tilt pattern at the Hawaiian Volcano Observatory: Volcano Letter, no. 495, p. 1-5.

Stearns, H. T., and Clark, W. O., 1930, Geology and water resources of the Kau District, Hawaii: U. S. Geol. Survey, Water Supply Paper 616, 194 p.

—_ and Macdonald, G. A., 1946, The geology and ground water resources of the island of Hawaii: Hawaii Div. Hydrography, Bull. 9, $363 \mathrm{p}$.

Verhoogen, J., 1948, Les éruptions 1938-1940 du volcan Nyamuragira: Inst. des Parcs Nationaux du Congo Belge, Exploration du Parc National Albert, Missions J. Verhoogen (1938 et 194.0), Fasc. 1, Bruxelles, 186 p.

Wilson, R. M., 1935, Ground surface movements at Kilauea Volcano, Hawaii: Hawaii Univ. Research Pub. no. 10, 56 p. 


\section{INDEX}

\begin{tabular}{|c|c|}
\hline Page & Page \\
\hline A $₫$ fronts and fields................... $63,71,78,81$ & composition of \\
\hline Abstract. & area................... \\
\hline Area of lava.............. & volume.................. \\
\hline Ash & flows, distribution of ... \\
\hline Bosch-Omori type seismograph _.......... $30,31,41$ & $\begin{array}{l}\text { river } \\
\text { Littoral explosion }\end{array}$ \\
\hline Braided lava streams.................... 54 & Narrative of the 1950 eruption.......... \\
\hline Cascades of lava......................... $66,67,69$ & Pahoehoe.................. \\
\hline 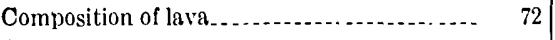 & Pohoiki, warm water at................... 47 \\
\hline Crack measurements....... $43,84-86$ & Punaluu Kahawai \\
\hline Distribution of lava flows............. pl 1 & Puu Kukae. \\
\hline Dome fountains & 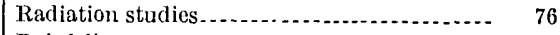 \\
\hline Earthquakes................ $31-41,49,82,84,86$ & Rainfall records \\
\hline $32,33.86$ & investigations..................... \\
\hline $35,36,82,84$ & $61,62,63,64,65,66,69$ \\
\hline distant............. 40 & Sprengnether seismograph...... . . . \\
\hline Eruption of Mauna Loa, $1950 \ldots$ & Steam \\
\hline "Fixed gases"'........ 46 & Kilanea, December $1950 \ldots \ldots . . . . .82-87$ \\
\hline Flows, distribution of $\ldots$ & passages......................... \\
\hline Fountains & 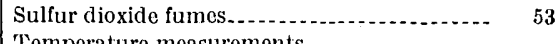 \\
\hline Fumes_... & 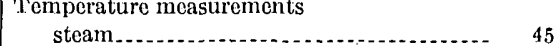 \\
\hline Geomagnetic observations................ 45 & lava................... $46,61,62,66,68,69,76$ \\
\hline $41-43,49,76,77$ & Thermal water on Kilauea volcano \\
\hline mau rain gage.................... 48 & Tilting \\
\hline $50,77-81$ & seasonal... \\
\hline 33 & annual variation. \\
\hline station._.............. 29, 30,38 & average annual. 41 \\
\hline$w_{n}$ & nos $\ldots \ldots . .42,43,48,76,77,86-87$ \\
\hline Fydraulic jump. & scismographs_............. 29 \\
\hline rbon gas. & Uwekahuna rain gage \\
\hline $57,58,59,60,61,62,63,68,69,72,73,81$ & Uwekahuna vault_............. 29-30, 48,82 \\
\hline & Volcanic conditions during $1950 \ldots \ldots$ \\
\hline 64,68 & Volume of lava....... 72,73 \\
\hline$\ldots 56,73,82$ & "Warm Spring" \\
\hline apoho. u & Will-o-the-wisps \\
\hline
\end{tabular}

